\title{
国立公園内に位置する大山寺集落と 御岳山山上集落の土地利用管理に関する研究 STUDY ON LAND USE MANAGEMENT OF DAISEN-JI VILLAGE AND MITAKESAN-SANJO VILLAGE IN NATIONAL PARKS
}

\author{
小椋弘佳*, 樋口＼cjkstart秀** \\ Hiroka OGURA and Shu HIGUCHI
}

\begin{abstract}
This study aims to clarify the situation of the land use management and the landownership change in the village located in special zone of National Park through the case study of Daisen-ji village and Mitakesan-Sanjyo village.

The land use of both villages has changed by the process of maintaining it as a service center in national park. For Daisen-ji village, a lot of landowners in and outside the village manage individually. Especially, the privately owned area has a lot of problems such as increase of the unused land with incomplete management. For Mitakesan village, the resident and the community composed of the resident owns not only the building lot but also the forest and uncultivated field and manages there with cooperation and adjustment. As a result, the land use doesn't change rapidly, and the land use management of the entire village space is enabled.
\end{abstract}

Keywords : Land Use Management, Landownership, National parks, Special Zones, Village

土地利用管理，土地所有，国立公園，特別地域，集落

\section{1. 研究の背景と目的}

日本の国立公園は，優れた自然景観を有しているが，土地所有に 関係なく区域を指定するため, 国有地のみならず公有地, 私有地が 存在する。その内部には多数の人々が暮らしており, 日常の生活を 行なう「地域」が形成されている公園も多い1)。そのため国立公園 制度は, 所管の環境省と地方自治体や民間事業者, 土地所有者, 地 域住民等の関係者が協働で管理することを前提に, 協働型管理体制 の構築が進められている223)。

一方, 国立公園は, 景観の重要性や保護の必要性の度合に応じて, 特別地域と普通地域等の地種区分注1)により土地利用が規制されて いる。加えて, 特別地域は, 優れた風致景観を有寸る地域であるこ との他に, 5 つの条件が挙げられており, その一つに「社寺, 史跡, 霊場, 伝説地, 伝統的又は風致的建築様式をそなえた集落地等の文 化景観が周囲の自然と相まって特徵ある景観を呈している地域」が 含まれる。このような集落の代表例に, 山岳信仰に由来する集落 (以 下, 山岳信仰集落）が挙げられる。

また，国立公園内に存在する集落の多くでは，国立公園の利用促 進を目的とした拠点整備が進められ, 集落そのものが公園利用の拠 点としての役割を担っている。特に, 山岳信仰集落を含む特別地域 内の集落は, 保護す心゙き景観の一部でもありながら, 利用拠点とし ても機能している。しかしながら, 著者らはこれまでに, 公園利用 の拠点として整備することを目的として特別地域内に指定された集 団施設地区 ${ }^{\text {注 } 2)} 119$ 地区の約 6 割には集落が存在するものの，その多
くで人口および世帯数が急激に減少していることを明らかにした4)。 また，世帯減による集落の衰退は，低・未利用地の発生など，国立 公園内の魅力や利用拠点としての役割の低下に繋がることを指摘し た。さらに，管理面からみると，地域住民の減少は協同管理の担い 手の不足に繋がる恐れがある。そのような中で，国立公園指定以前 から現在まで，長期にわたり地域住民によって維持されてきた固有 の文化や景観を有する山岳信仰集落は, 独特の土地利用管理が実施 されてきた可能性がある。今後の国立公園内の集落維持・管理のあ り方を考える上では, このような山岳信仰集落の土地利用管理の実 態解明は重要になると考える。

国立公園内の地域に関する既往研究としては, 公園管理に着目し て地域住民の担う役割の重要性を論じた研究5), 国立公園のあり方 に関する地域レベルでの合意形成プロセスの必要性を論じた文献6) がある。特定の地域を対象としたものには，磐梯朝日国立公園の土 地所有状況を明らかにした上で，国立公園計画の決定手続きに住民 や地権者の参加制度が不在であること等の課題を明らかにした研究 7)がある。しかしながら, 具体の集落を取り上げて, その変容と合 わせた土地所有や土地利用管理の実態を明らかにした研究蓄積は未 だ少ない8)。

そこで, 本研究は, 国立公園特別地域に位置する山岳信仰集落の 中から, 鳥取県西伯郡大山寺集落（以下, 大山寺）と, 東京都青梅 市御岳山山上集落（以下，御岳山）を取り上げ，国立公園制度とと もに変容してきた両集落内の土地利用・土地所有形態，土地・建物 
の管理実態，そして主な土地所有者である住民の意向を把握するこ とから, 集落内の土地利用管理と, 今後の集落維持に向けた課題解 明を目的とする。

\section{2. 研究の構成と方法}

\section{2-1 研究対象地の選定と概要}

山岳信仰集落は，霊山とのかかわりにおいて形成された門前町と 定義され ${ }^{9)}$, 近世から宿泊機能を有寸観光の拠点としても機能する 歴史的集落である。本研究での対象地を選定するために, 全国に存 在する山岳信仰集落として, (1)国内門前町リスト170の集落 ${ }^{10)}$ のうち, (2)霊山とのかかわりにおいて形成された門前町 $39^{11}$ に, (3)環境省自 然保護官へのアンケートから得られた集落注3)を加えた44集落を抽 出し, 国立公園区域との関係により整理した（図1)。その結果, 国 立公園内の特別地域内には 8 集落が存在し, そのうち 5 集落が集団 施設地区に指定されていた。本研究では, 集団施設地区に指定され た中から大山寺と, 特別地域のみの集落から御岳山を選定した。

大山寺集落は, 大山 $(1729 \mathrm{~m})$ を信仰対象とし, 大山寺, 大神山神 社が集落の最上部に位置する門前町である(表 1 , 図 2 )。御岳山は, 御岳山 $(929 \mathrm{~m})$ を信仰対象とし, 武州御岦神社が集落の最上部及び 御岳山の山頂に位置寸る門前町である（表 1 , 図 3 )。また, 両集落 の自然公園法に基づく地種区分はともに第二種特別地域であり, 両 者とも1954年に集団施設地区に指定されている。しかしながら, 大 山寺は現在も集団施設地区として整備されているが, 御岳山は, 2000 年に環境省で公園計画の全般的な見直しが行われた際に集団施設地 区の指定が解除されている注4)，12)。両集落は，国立公園指定当時か ら利用拠点として整備されてきた集落ではあるが, その変容や土地 利用管理には差異や特徵があると考えられるため, 本研究ではこの 2 集落を取り上げて詳細な実態を解明することとした。

\section{2-2 研究の構成と方法}

3 章では大山寺を，4章では御岳山をそれぞれ事例分析した。分 析項目は, (1)集落の形成過程, (2)土地利用と土地所有変化, (3)土地 建物の管理実態, (4)土地所有者の意識, (5)公園事業に関する宿舎事 業の許認可履歴と認可の理由, である。これらの結果を踏まえて 5 章では, 両集落を比較し考察した。

各項目の調查方法は以下の通りである。(1)集落の形成過程は, 町 誌 ${ }^{131}$ 14) $^{2}$ 中心とした資料より把握した。(2)土地利用・土地所有変化 は, 土地台帳を閲覽し， 3 時点の地目, 所有者, 面積をデータベー ス化した 注5)。さらに地籍図を空間化し土地情報と結合した。調査対 象年は, 自然公園法制定以前の状況及び集団施設地区指定以前の姿 を示す1945年, 過剩利用による自然環境破壊に対する自然保護活動 が活発になる前で, 集団施設地区指定後の姿を示す1970年, 直近の 集落の姿を示す 2010 年の 3 時点とした。(3)土地・建物の管理実態は, (2)の調查で把握した土地所有者や自然保護官に対して, 土地と建物 の管理者についてのヒアリングを行なった。(4)土地所有者の意識は, 両集落の全世帯主を対象にアンケート調查を実施し把握した (表 2 )。 調查項目は, 回答者の属性, 土地所有の意向, 継続居住の意向等で ある。継続居住の意向に関寸る質問等は, 世帯主以外の 20 歳以上の 住民からも回答を得た。(5)公園事業の履歴は, 公園計画で定められ る「公園事業」注 6$)$ のうち宿舎事業に着目し, その許認可履歴と認可 の理由を分析した。

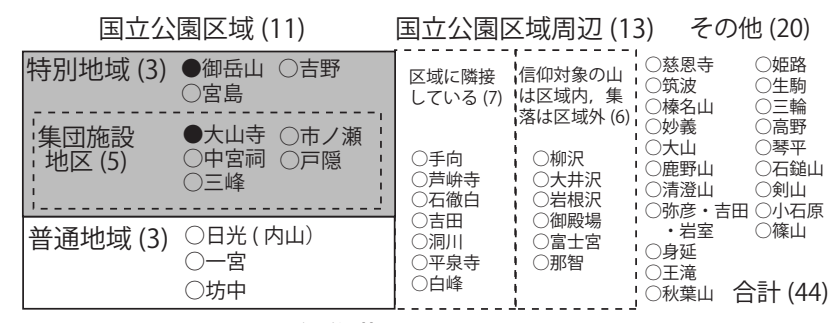

図 1 山岳信仰集落と国立公園区域との関係図

表 1 調査対象地の概要

\begin{tabular}{|c|c|c|}
\hline 集落 名 & 大山寺集落 & 御岳山山上集落 \\
\hline 住 & 鳥取県西伯郡大山寺 & 東京都青梅市御岳山 \\
\hline 標 & 約900m & 約 $900 \mathrm{~m}$ \\
\hline 人 & 130人 (H22国勢調査) & 146人 (H22国勢調査) \\
\hline 霊 & 大山 & 御岳山 \\
\hline 社 & 大神山神社, 大山寺 & 武州御嶽神社 \\
\hline 国立公園 & 大山隠岐国立公園 & 秩父多摩甲斐国立公園 \\
\hline 区 & 第2種特別地域＋集団施設地区 & 第2種特別地域 \\
\hline
\end{tabular}

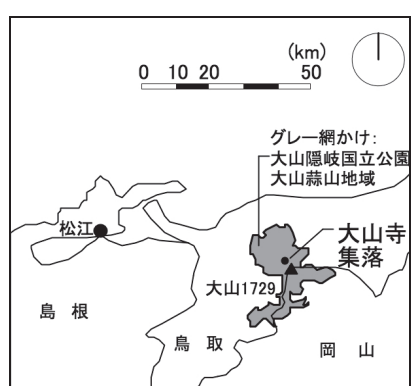

図 2 大山寺集落位置図

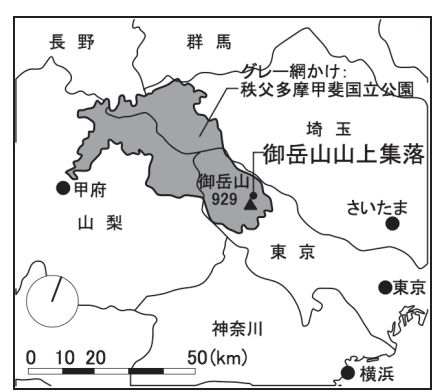

図 3 御岳山山上集落位置図
表 2 アンケート調査概要

\begin{tabular}{|c|c|c|}
\hline & 大山寺集落 & 御岳山山上集落 \\
\hline 調査対象 & 全世帯主 & 全世帯主 \\
\hline 調査 時期 & $2010.12 .2 \sim 2011.3 .21$ & $2011.9 .29 \sim 2011.11 .2$ \\
\hline 調 査 数 & 世帯主 : 53 & 世帯主 : 44 \\
\hline 回収 数 & 44 & 31 \\
\hline 回収 率 & $83 \%$ & $71 \%$ \\
\hline 配 布 回収 & 訪問配布・訪問回収 (－部郵送) & 御師集会時に配布, 郵送回収 \\
\hline & 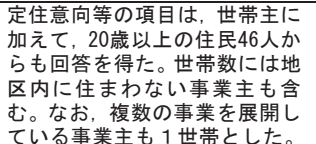 & $\begin{array}{l}\text { 定住意向等の項目は, 世帯主に加 } \\
\text { えて,20歳以上の住民 } 37 \text { 人からも } \\
\text { 回答を得た。調査対象には, 滝本 } \\
\text { 集落の御師家6世帯を含む。 }\end{array}$ \\
\hline $\begin{array}{l}\text { アンケー } \\
\text { ト 項 目 }\end{array}$ & \multicolumn{2}{|c|}{ 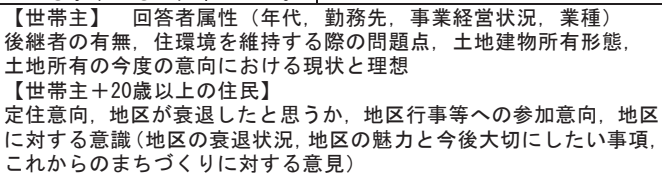 } \\
\hline
\end{tabular}

\section{3. 大山寺集落の土地利用管理}

\section{3-1 集落の形成過程}

大山寺は奈良時代に開山し, 中世には 3000 人の僧兵を擁した山岳 修行の場であった。2011年の僧坊跡調查委員会の報告には, 大山寺 周辺は，僧坊の大半は現存しないが, 160箇所前後の僧坊跡と考えら れる平坦面が確認されたと記載されている ${ }^{15)}$ 。宿坊跡の調查範囲は, 図 4 の1945年土地利用变遷図に示寸。1868 (明治元) 年に廃仏毁勫を 命ぜられ，1875年に大山寺号が廃絶すると集落は急速に衰退した。 その後1920年代に入ると, 鳥取県下で初めてのスキー講習会が集落 の入口に位置する博労座で開催され，レジャー観光に向けた転機と なった。また，同県米子市民を中心に大山スキークラブや米子道明 山岳会が結成された。この山岳会は, 自らが山登りを実践するだけ ではなく, 登山の普及発展と大山国立公園の発展開発をねらいとし た幅広い活動を目的としていた。このころから近隣市町村も含めた レジャー利用が活発になった(図 4 上)。そして，1936年に大山寺は 
【自然公園法及び集団施設地区制度の変遷】

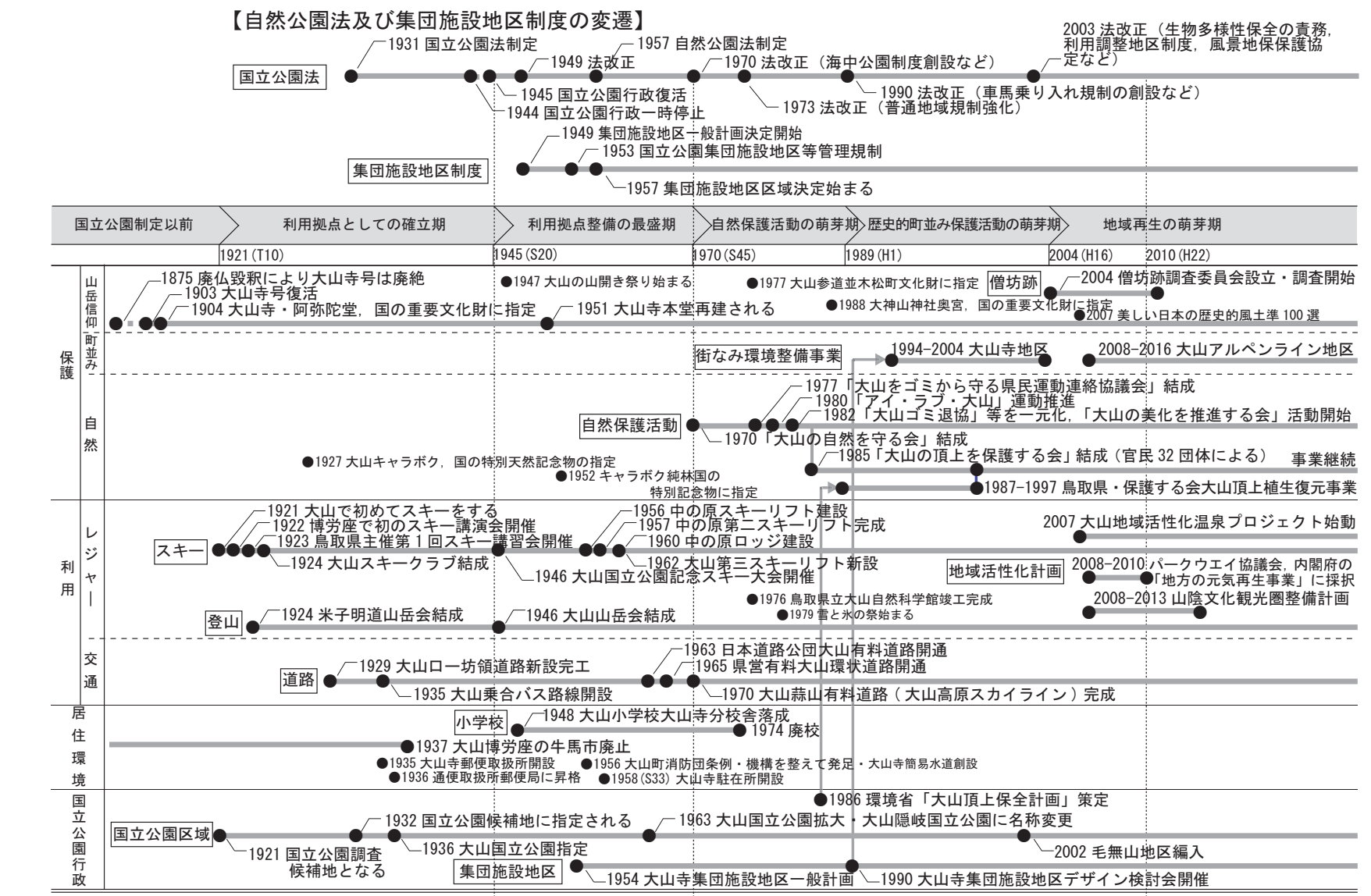

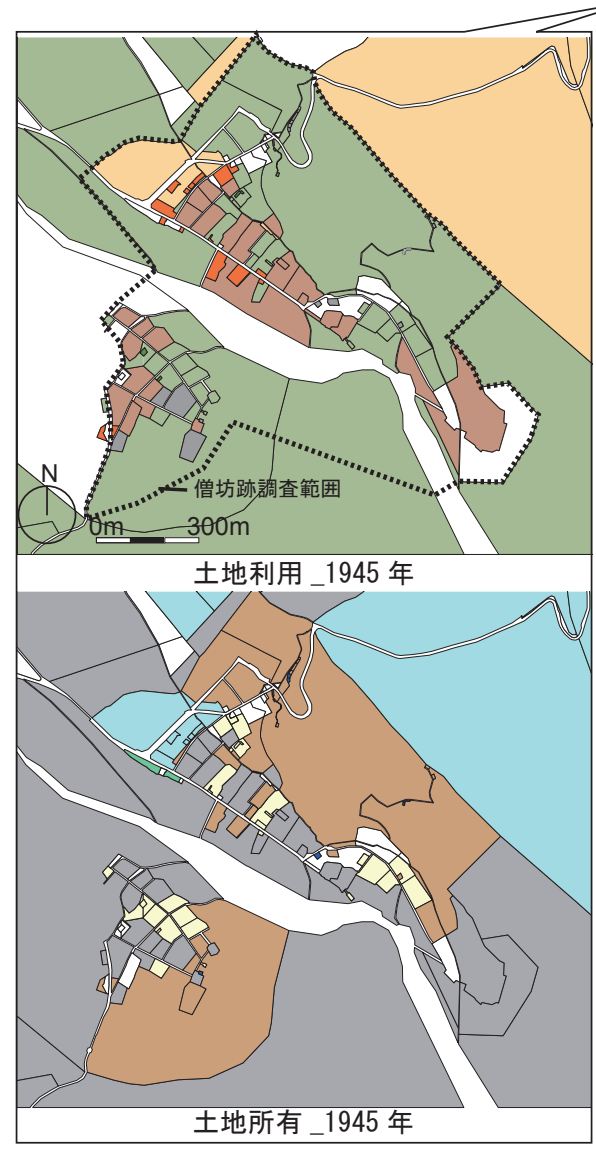

凡例： $\square$ 宅地 $\square$ 原野 $\square$ 畑 $\square$ 不明 土地利用 $\square$ 山林 $\square$ 社寺境内地 $\square$ その他

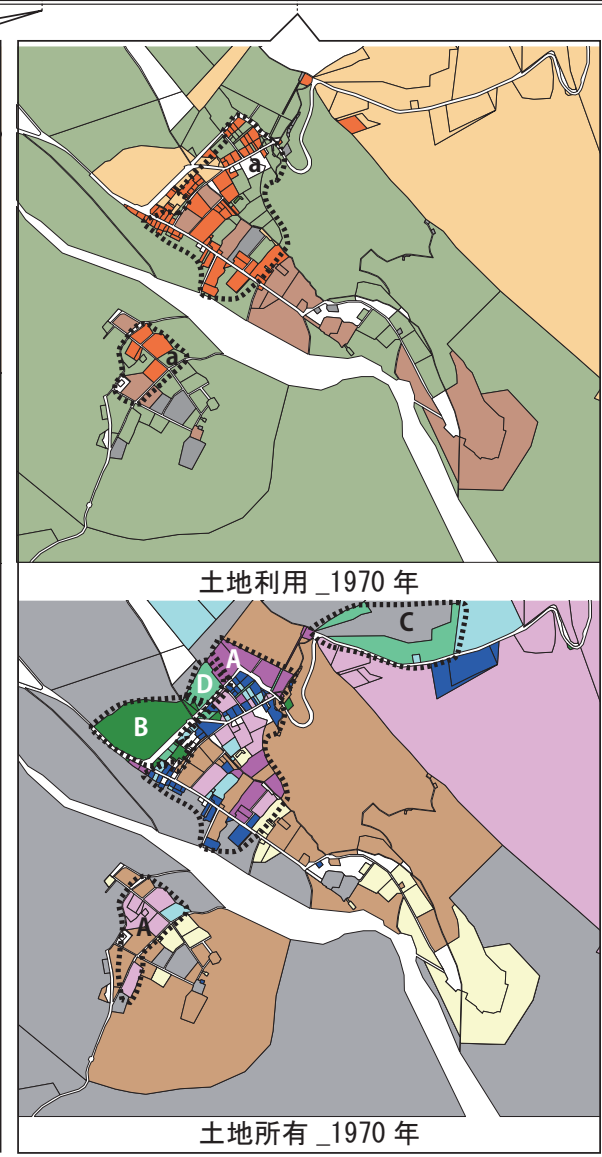

凡例： 個人(地区内) $\square$ 会社(地区内)

土地所有者 $\square$ 個人(地区外) $\square$ 会社(地区外)

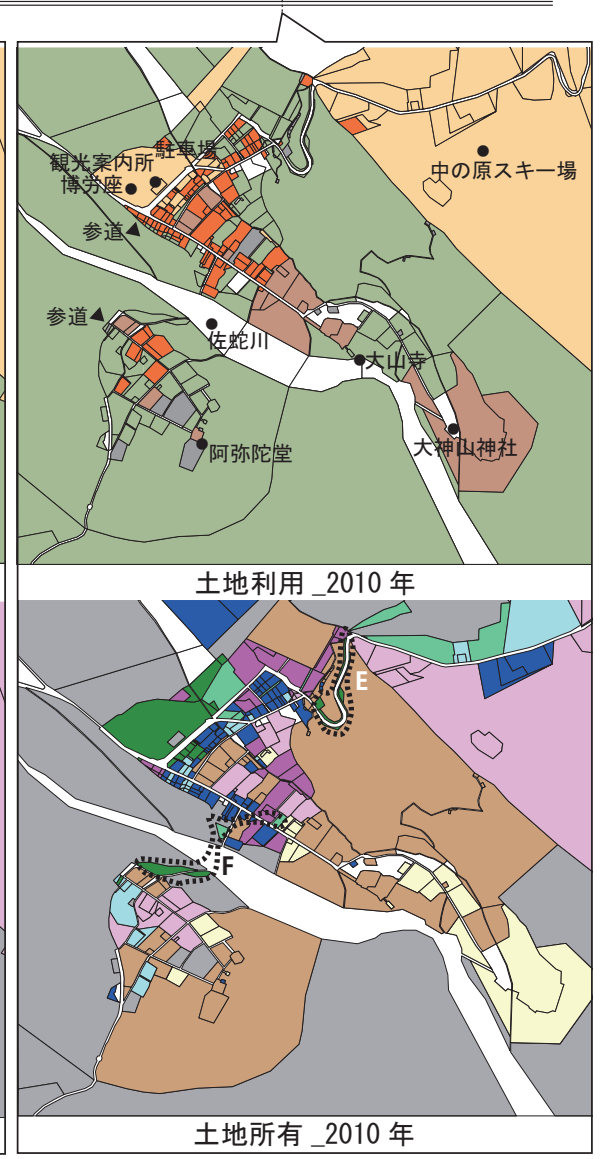

$\square$ 神社(大神山神社) $\square$ 国 $\square$ 大山町

$\square$ 寺 (大山寺·その他僧坊) $\square$ 鳥取県 $\square$ 不明

図 4 大山寺の変遷 (上) と土地利用 - 土地所有変遷図 $($ 下) 
国により山岳信仰集落としての景観的・文化的価值が評価されて, 大山国立公園に指定された。国立公園指定後は, 小学校や郵便局等 の住環境整備とともに, 民間企業によるスキー場整備や大会誘致, 有料道路等の交通整備が同時期に進んだ。集団施設地区に指定され た1954年前後に利用拠点整備の最盛期を迎え，レジャー観光の拠点 に転換したといえる。1970年代は, それまでの公園の過剩利用の反 省から官・民による環境美化活動や自然保護の動きが活発になった。

また，1990年に行なわれた環境庁（現・環境省）の事業「良好な 自然環境地域における適正利用促進計画策定調查（リフレッシュプ ラン)」を契機に自治会, 町, 県, 専門家らを中心とする大山寺集 団施設地区デザイン検討会が発足した。この検討会は, 歴史的町並 みを新たな鬼力として見直すことを目的に大山寺参道のデザイン報 告書を作成した。報告書の内容は1994年から10年間で行われた大山 寺地区街なみ環境整備事業に反映された。このように, 官民協働で 歴史的町並夕を見直し, 再生しようとする動きが芽生えた。さらに, 2000 年代以降は, 民間企業主導の地域活性化計画策定, NPO法人と鳥 取県主導の大山寺を含む鳥取・島根両県を対象とした広域観光ルー トづくり, 大山町教育委員会を中心とする僧坊跡調查委員会の発足, 鳥取県主導の町並み整備の実施など, 集落住民以外の官・民さまざ まな主体による地域活性化を目指した活動が始まっている。

\section{3-2 土地利用変化と土地所有変化}

\section{(1) 土地利用変化}

前節で整理した集落の変化を土地利用の変化から確認する。土地 利用は, 土地台帳に記載された土地（筆）の地目により把握した。

まず, 集落内の合計筆数は, 1945年196筆, 1970年342筆, 2010年 442筆と増加しており, 分筆が顕著である(表 3 )。変化した土地の位 置は, 大山寺や大神山神社, 阿弥陀堂の参道沿いに集中している(図 4-土地利用1970-a)。

年代別に地目構成をみると, 1945 年は山林が $40 \%$ と最多で, 次い で社寺境内地 $16 \%$, 原野10\%であった（表 3 ）。1970年は山林が36\% と最多であるが減少しており, 宅地が $27 \%$ と急増している。地目別 に筆数変化をみると, 宅地は1945-1970年の間（以下，前期）に約 4 倍増加した。一方で, 社寺境内地は前期に $3 / 4$ に減少した。1954 年の集団施設地区指定前後 (利用拠点整備の最盛期) に, 分筆を伴
う宅地の増加により, 地目の構成比は大きく変化した。前期に, 社 寺境内地から宅地一変化した土地の多くは宿泊施設兼住宅として利 用されている。その後, 1970-2010年の間（以下，後期）では, 変化 数は減るものの, 引き続き宅地化が進んだことが窥える。また，社 寺境内地から山林に変更されたものは, 境内地として利用されなく なった土地を山林に変更したものである。

\section{(2) 土地所有変化}

土地利用の変化に大きく影響を与える土地所有の変化をみる。ま ず, 年代別に土地所有の筆数構成比をみると, 1945年は公共団体 (国, 県, 町を含む) が $40 \%$, 社寺（神社, 寺, その他社寺・宿坊を含む) が33\%と多い(表 3)。1970年は, 公共団体が30\%で最も多く, 次い で個人 $27 \%$, 社寺 $23 \%$ である2010年は，1970年の構成とほとんど 変わらない。個人の筆数は, 前期に 27 筆から 91 筆と増加し, 法人も 1945 年 0 筆から 1970 年 45 筆, 2010 年には 73 筆と増加が顕著である。

次に, 土地所有変化の詳細とその要因を考察した注7)。前期は201 筆 $\left(933,757 \mathrm{~m}^{2}\right)$ の変化がみられた（表 4 左）。そのうち，個人への 変化は 75 筆 $(37 \%)$, 次いで法人へは45筆 $(22 \%)$ と多い。個人や法 人への変化は, 公共団体や社寺から分筆・変更されたものである。

表 3 年代別にみた土地利用と土地所有の関係（大山寺）（筆）

\begin{tabular}{|c|c|c|c|c|c|c|c|c|c|c|}
\hline & & 宅地 & 山林 & 原野 & $\begin{array}{c}\text { 社寺境 } \\
\text { 内地 }\end{array}$ & 畑 & その他 & 不明 & \multicolumn{2}{|c|}{ 計 } \\
\hline \multirow{6}{*}{ 年 } & 個人 & & 3 & 8 & & & 9 & & & \\
\hline & 社寺 & 9 & 39 & & 1 & 3 & 11 & 1 & 64 & $33 \%$ \\
\hline & 忩共団体 & & 35 & 10 & 30 & & 3 & i & 79 & $40 \%$ \\
\hline & 栄明 & & 2 & 2 & if & & & 21 & & $13 \%$ \\
\hline & I計 & 16 & 79 & 20 & 32 & 3 & 23 & 23 & \multicolumn{2}{|c|}{196} \\
\hline & |柿 & $8 \%$ & $40 \%$ & $10 \%$ & $16 \%$ & $2 \%$ & $12 \%$ & $12 \%$ & \multicolumn{2}{|c|}{$100 \%$} \\
\hline \multirow{7}{*}{$\begin{array}{l}1 \\
9 \\
7 \\
0 \\
0 \\
\text { 年 }\end{array}$} & 個人 & 54 & 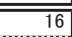 & 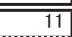 & & $=1$ & $\overline{\overline{9}}$ & 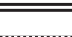 & & $27 \%$ \\
\hline & 法人 & 15 & 18 & 10 & & & 2 & & 45 & $13 \%$ \\
\hline & 社祔 & 12 & 40 & & 15 & ${ }_{1}$ & 11 & 1 & 80 & $23 \%$ \\
\hline & 公共団体 & 111 & 46 & 24 & 8 & & 12 & 1 & 102 & $30 \%$ \\
\hline & 栄明 & & 3 & 2 & 1 & & & 18 & 24 & $7 \%$ \\
\hline & \multirow{2}{*}{ 計 } & 92 & 123 & 47 & 24 & $\overline{2}$ & 34 & 20 & \multicolumn{2}{|c|}{$\begin{array}{r}342 \\
340 .\end{array}$} \\
\hline & & $27 \%$ & $36 \%$ & $14 \%$ & $7 \%$ & $1 \%$ & $10 \%$ & $6 \%$ & \multirow{2}{*}{\multicolumn{2}{|c|}{$100 \%$}} \\
\hline \multirow{7}{*}{$\begin{array}{l}2 \\
0 \\
1 \\
0 \\
\text { 年 }\end{array}$} & 個人 & 265 & 33 & 17. & 1 & $\overline{1.1}$ & 9 & 7.1 & & $29 \%$ \\
\hline & 法人 & 27 & 33 & 111 & & & $\ldots$ & & 73 & $17 \%$ \\
\hline & 社等 & 13 & 43 & & 19 & & 12 & 1 & 88 & $20 \%$ \\
\hline & 忩共团体 & 11 & 66 & 34 & 3 & & 20 & 1 & 135 & $31 \%$ \\
\hline & 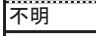 & & & 1 & & & & 18 & 19 & $4 \%$ \\
\hline & \multirow{2}{*}{ 計 } & 116 & 175 & 63 & 23 & .1 & 43 & 21 & \multicolumn{2}{|c|}{442} \\
\hline & & $26 \%$ & $40 \%$ & $14 \%$ & $5 \%$ & $0 \%$ & $10 \%$ & $5 \%$ & 100 & \\
\hline
\end{tabular}

表4 1945-1970-2010年の土地所有変化 (大山寺) 注8)

\begin{tabular}{|c|c|c|c|c|c|c|c|c|c|c|c|c|c|c|c|c|c|c|c|}
\hline \multirow{2}{*}{\multicolumn{2}{|c|}{$\begin{array}{l}\text { 上段:筆数(筆) } \\
\text { 下段:面積 }\left(\mathrm{m}^{2}\right)\end{array}$}} & \multicolumn{10}{|c|}{ 1970年 土地所有 } & & \multirow[b]{2}{*}{$\begin{array}{l}\text { 筆数(筆) } \\
\text { 面積 }\left(\mathrm{m}^{2}\right)\end{array}$} & \multicolumn{6}{|c|}{ 2010年 土地所有 } \\
\hline & & \multirow{2}{*}{$\begin{array}{r:}\text { 個人 } \\
16 \\
90,257\end{array}$} & \multirow[t]{2}{*}{\begin{tabular}{|l|} 
分筆前 \\
(個人)
\end{tabular}} & \multirow{2}{*}{\begin{tabular}{|r} 
法人 \\
4 \\
413,666
\end{tabular}} & 社寺 & $\begin{array}{l}\text { 分筆前 } \\
\text { (社寺) }\end{array}$ & \multirow{2}{*}{ 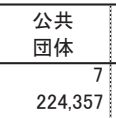 } & $\begin{array}{l}\text { 分筆前 } \\
\text { (公共団体) }\end{array}$ & 不明 & $\begin{array}{r}\text { 分筆前 } \\
\text { (不明) }\end{array}$ & 総計 & & & 個人 & 法人 & 社寺 & $\begin{array}{l}\text { 公共 } \\
\text { 団体 } \\
\end{array}$ & \multirow[t]{2}{*}{ 不明 } & 総計 \\
\hline & 個人 & & & & & & & & & & $\begin{array}{r}27 \\
728,281\end{array}$ & & 個人 & \begin{tabular}{r|}
82 \\
140,328
\end{tabular} & $\begin{array}{r}7 \\
5,349\end{array}$ & $\begin{array}{l}1 \\
0\end{array}$ & $\begin{array}{r}1 \\
642\end{array}$ & & $\begin{array}{r}91 \\
146,319\end{array}$ \\
\hline & $\begin{array}{r}\text { 分筆前 } \\
\text { (個人) }\end{array}$ & $\begin{array}{r}17 \\
37,928\end{array}$ & $\begin{array}{r}20 \\
62,361\end{array}$ & $\begin{array}{r}7 \\
12,031\end{array}$ & & & $\begin{array}{r}19 \\
44,288\end{array}$ & & & & $\begin{array}{r}63 \\
156,608\end{array}$ & & $\begin{array}{r}\text { 分筆前 } \\
\text { (個人) }\end{array}$ & $\begin{array}{r}7 \\
2,240\end{array}$ & $\begin{array}{r}1 \\
6,814\end{array}$ & & \begin{tabular}{r|}
12 \\
53,307
\end{tabular} & & $\begin{array}{r}20 \\
62,361\end{array}$ \\
\hline & 法人 & - & $\begin{array}{l}- \\
-\end{array}$ & $\begin{array}{l}- \\
-\end{array}$ & - & - & - & - & - & - & $\begin{array}{l}- \\
-\end{array}$ & & 法人 & $\begin{array}{r}3 \\
429\end{array}$ & $\begin{array}{r}41 \\
467,518\end{array}$ & & $\begin{array}{r}1 \\
59\end{array}$ & & $\begin{array}{r}45 \\
468,006\end{array}$ \\
\hline 1 & 社寺 & $\begin{array}{r}7 \\
6,722\end{array}$ & & $\begin{array}{r}6 \\
8,360\end{array}$ & $\begin{array}{r}49 \\
274,314\end{array}$ & & $\begin{array}{r}2 \\
8,632\end{array}$ & & & & $\begin{array}{r}64 \\
298,029\end{array}$ & $\mid \begin{array}{ll}1 \\
9\end{array}$ & 社寺 & $\begin{array}{r}6 \\
2,097\end{array}$ & $\begin{array}{r}5 \\
5,951\end{array}$ & $\begin{array}{r}69 \\
337,177\end{array}$ & & & $\begin{array}{r}80 \\
345,225\end{array}$ \\
\hline 4 & $\begin{array}{r}\text { 分筆前 } \\
\text { (社寺) }\end{array}$ & $\begin{array}{r}35 \\
8,116\end{array}$ & & $\begin{array}{r}10 \\
12,656\end{array}$ & $\begin{array}{r}88 \\
1,075\end{array}$ & $\begin{array}{r}29 \\
17,193\end{array}$ & $\begin{array}{r}11 \\
4,317\end{array}$ & & & & $\begin{array}{r}93 \\
43,357\end{array}$ & $\begin{array}{l}9 \\
7 \\
0\end{array}$ & $\begin{array}{r}\text { 分筆前 } \\
\text { (社寺) }\end{array}$ & $\begin{array}{r}6 \\
641\end{array}$ & $\begin{array}{r}5 \\
2,790\end{array}$ & $\begin{array}{r}8 \\
10,350\end{array}$ & $\begin{array}{r}10 \\
3,412\end{array}$ & & $\begin{array}{r}29 \\
17,193\end{array}$ \\
\hline 年 & 公共団体 & & & $\begin{array}{r}7 \\
10,641\end{array}$ & $\begin{array}{r}18 \\
61,758\end{array}$ & & \begin{tabular}{r|}
53 \\
$16,872,423$
\end{tabular} & & $\begin{array}{r}1 \\
33,043\end{array}$ & & $\begin{array}{r}40,007 \\
79 \\
16,977,864\end{array}$ & $\begin{array}{l}0 \\
\text { 年 }\end{array}$ & 公共団体 & \begin{tabular}{r|}
041 \\
2 \\
1,451
\end{tabular} & & $\begin{array}{r}10,350 \\
5 \\
18,437\end{array}$ & $\begin{array}{r}3,412 \\
95 \\
17,158,271\end{array}$ & & $\begin{array}{r}1 /, 193 \\
102 \\
17,178,159\end{array}$ \\
\hline $\begin{array}{l} \pm \\
\text { 地 }\end{array}$ & $\begin{array}{r}\text { 分筆前 } \\
\text { (公共団体) }\end{array}$ & $\begin{array}{r}16 \\
3,295\end{array}$ & & $\begin{array}{r}8 \\
4,751\end{array}$ & & & \begin{tabular}{r|}
9 \\
24,140
\end{tabular} & $\begin{array}{r}49 \\
189,272\end{array}$ & & & $\begin{array}{r}82 \\
221,459\end{array}$ & 土 & $\begin{array}{r}\text { 分筆前 } \\
\text { (公共団体) }\end{array}$ & $\begin{array}{r}19 \\
11,309\end{array}$ & $\begin{array}{r}12 \\
4,966\end{array}$ & $\begin{array}{r}2 \\
2,200\end{array}$ & $\begin{array}{r}16 \\
170,797\end{array}$ & & $\begin{array}{r}49 \\
189,272\end{array}$ \\
\hline $\begin{array}{l}\text { 所 } \\
\text { 有 }\end{array}$ & 不明 & & & & $\begin{array}{r}3 \\
6,832\end{array}$ & & & & $\begin{array}{r}23 \\
471\end{array}$ & & \begin{tabular}{r|}
26 \\
7,304
\end{tabular} & $\begin{array}{l}\text { 所 } \\
\text { 有 }\end{array}$ & 不明 & $\begin{array}{r}1 \\
57\end{array}$ & $\begin{array}{r}2 \\
112\end{array}$ & $\begin{array}{r}2 \\
33,200\end{array}$ & & \begin{tabular}{r|}
19 \\
145
\end{tabular} & $\begin{array}{r}24 \\
33,514\end{array}$ \\
\hline & $\begin{array}{r}\text { 分筆前 } \\
\text { (不明) }\end{array}$ & & & $\begin{array}{r}3 \\
5,902 \\
\end{array}$ & $\begin{array}{r}2 \\
1,245\end{array}$ & & $\begin{array}{l}1 \\
1\end{array}$ & & & $\begin{array}{r}2 \\
281\end{array}$ & $\begin{array}{r}8 \\
7,429\end{array}$ & & $\begin{array}{r}\text { 分筆前 } \\
\text { (不明) }\end{array}$ & $\begin{array}{r}1 \\
131\end{array}$ & & $\begin{array}{r}1 \\
150\end{array}$ & & & $\begin{array}{r}2 \\
281\end{array}$ \\
\hline & 1945-1970年 & 75 & 0 & 45 & 31 & 0 & 49 & 0 & & 0 & 201 & & 1945-1970年 & 45 & 32 & 19 & 40 & 0 & 136 \\
\hline & で変化した筆 & 56,061 & 0 & 468,006 & 70,910 & 0 & 305,736 & 0 & 33,043 & 0 & 933,757 & & で変化した筆 & 18,355 & 25,981 & 64,337 & 228,218 & 0 & 336,891 \\
\hline & 総計 & $\begin{array}{r}91 \\
146,319\end{array}$ & $\begin{array}{r}20 \\
62,361\end{array}$ & $\begin{array}{r}45 \\
468,006\end{array}$ & $\begin{array}{r}80 \\
345,225\end{array}$ & $\begin{array}{r}29 \\
17,193\end{array}$ & $\begin{array}{r}102 \\
17,178,159\end{array}$ & $\begin{array}{r}49 \\
189,272\end{array}$ & $\begin{array}{r}24 \\
33,514\end{array}$ & $\begin{array}{r}2 \\
281\end{array}$ & $\begin{array}{r}442 \\
18,440,330\end{array}$ & & 総計 & \begin{tabular}{r|}
127 \\
158,683 \\
\end{tabular} & $\begin{array}{r}73 \\
493,500\end{array}$ & \begin{tabular}{|r|}
88 \\
401,513
\end{tabular} & $\begin{array}{r}135 \\
17,386,488\end{array}$ & $\begin{array}{r}19 \\
145\end{array}$ & $\begin{array}{r}442 \\
18,440,330\end{array}$ \\
\hline
\end{tabular}


この変更の目的は, 需要に応じて宿泊施設を増加させるための宅地 化である注9) (図 4-土地所有1970-A)。なお, 面積の変化が大きい個 人から法人への変化は, 主にスキー場用地への転用である。また, 公共団体へは 49 筆 $(24 \%)$ の変化があった。そのうち, 個人（分筆 前個人を含む）から公共団体一変化したものが 26 筆と多く, 面積も 268, $645 \mathrm{~m}^{2}$ を占める。これは, 一部山林を官有地に変更するためのも のが含まれるが, 大半は大山自然歴史館や博労座広場等の整備（図 4-同B）や，スキー場の整備（図 4-同C）のための変化である。面 積の大きい, 社寺から公共団体への変化 ( 2 筆) は, 公園利用者の ための駐車場整備を目的としている (図 4-同D)。このように, 前 期では公園利用施設の整備に伴い, 公共団体・社寺を中心とした土 地所有構造から，個人・法人所有が加わった構造に変容している。

後期の土地所有変化は 136 筆 $\left(336,891 \mathrm{~m}^{2}\right)$ であった（表 4 右）。前 期に比べて変化量は小さいが, そのうち, 個人への変化が45筆 (33\%), 法人への変化が 32 筆 $(26 \%)$ と多い。特に, 公共団体から個人に分 筆したものが19筆 $\left(11,309 \mathrm{~m}^{2}\right)$ ある。これは, 県道沿いの宿舎等の 駐車場用地一の転用である。個人から法人に分筆した 1 筆は, 面積 が $6,814 \mathrm{~m}^{2}$ と大きいが, これはスキー場開発に伴う変化である。加え て, 公共団体への変化も 40 筆 $(29 \%)$ と多い。これは, 山林の所有 者の変更や, 道路拡幅のためである(図 4-土地所有2010-E)。また, 広面積の変化である個人から公共団体への分筆は, 総合体育館用地 への変更に伴うものである。その他にも, 駐車場や広場, ギャラリ 一の整備のために, 公共団体の所有が増加している (図 4-同F)。

このように, 土地所有の筆数及び面積の変化は減少するものの, 後期でもスキー場や, 駐車場, 道路の整備に伴い, 個人・法人所有 の所有が増加し, 広い面積での公共団体への変化がみられた。

土地所有変化のあった位置をみると, 大山寺, 大神山神社一の参 道沿いと, 阿弥陀堂への参道沿いに集中している。これは, 土地利 用変化の著しいエリアと重なっているため, 集落の土地利用の変容 は, 土地所有者の所有状況の変化と連動しているといえる(図 4 下)。

\section{3-3 2010年の土地所有別の土地利用実態と土地・建物の管理者}

個人と法人所有の土地（以下, 私有地）は, 集落内外の土地所有 者により, 主に宅地として利用・管理されている。特に企業による 別荘としての利用も多い。また, 中には空き家, 空地となっている ものもあり, 管理方法に課題がある。しかし現状では具体的な対応 策はない注10)。社寺所有の土地 (以下, 社寺有地) は, 大きな面積 を占めるものの, 各社寺によって管理される。他方, 町と県, 国所 有の土地 (公有地) は, 主に山林や原野として利用・管理されてい る。参道沿い唯一の町有地は, 観光客向けのギャラリーとして利用 されている (図 4-土地所有2010-F)。施設の管理は, 指定管理業務 委託によって一般社団法人大山観光局に委託されている。その他に もスキー場に隣接するスポーツ公園や, 県有地の駐車場, 大山自然 歴史館, 国有地の観光案内所も同様に, 大山観光局が国や鳥取県よ り指定管理業務を受託している。以上より, 大山寺の土地と建物の 管理は多様な土地所有者に委衫られていること, 国立公園の各利用 施設は大山観光局により一体的な管理がされていることが明らかと なった。しかしながら, 土地所有形態が多様で, 流動的であるにも かかわらず，それをコントロールする仕組みは存在しない。

\section{3-4 住民意識}

このような状況に対する住民の意識と今後の意向をみる。アンケ
ートの回答を得た世帯主の年代は, 50 代と60代が中心であった (表 2 , 表 5 )。勤務地は世帯主 $68 \%$ ，20歳以上の住民 $72 \%$ と共に集落内が最 も多く職住一体の形を取っている(表 6 )。土地・建物の所有形態は, 持地持家が75\%と多く(図 5)，70\%の世帯で現在事業を経営してい る (図 6 )。業種は, 宿泊業が 28 人で大半を占める他, 飲食業, 土産 店, スキー用品店などの小売業がみられた (図 7 )。また, 現在事業 を経営している世帯の $47 \%(14 / 30)$ には後継者がおらず, そのうち 64\% (9/14) は後継者を検討していない(図 8)。ここから大山寺では 後継者難が顕著であるといえる。定住意向は, 「住み続けたい」が $56 \%$, 「住み続けたいが移らざるを得ない」が11\%で， 7 割が定住意向を 示した(図 9)。一方で,「引っ越したいが住み続けるしかない」,「で きれば引っ越したい,引っ越す予定」が 3 割で非定住意向を示した。 土地所有の今後の意向では, 理想では「存続」が76\%であるものの, 現状では所有を存続させる予定が $58 \%$ で, 現状と理想に差がある(図 10)。集落の先行きに不安を感じ「未定」と答えた世帯主が $30 \%$ であ るなど, 今後さらに私有地の土地所有が変化することが予測できる。

\begin{tabular}{l|c|c|c|c|c|c|c|c|c|} 
表 5 & アンケート回答者の年代（大山寺） & \multicolumn{3}{l|}{ (人) } \\
\hline & 20 代 & 30 代 & 40 代 & 50 代 & 60 代 & 70 代 & 80 代 & 無回答 & 計 \\
\hline 世帯主 & $2 \%(1)$ & $5 \%(2)$ & $16 \%(7)$ & $36 \%(16)$ & $21 \%(9)$ & $14 \%(6)$ & $7 \%(3)$ & $0 \%(0)$ & 44 \\
\hline 20 歳以上住民 & $13 \%(6)$ & $11 \%(5)$ & $15 \%(7)$ & $26 \%(12)$ & $20 \%(9)$ & $13 \%(6)$ & $2 \%(1)$ & $0 \%(0)$ & 46 \\
\hline
\end{tabular}

\begin{tabular}{|c|c|c|c|c|c|c|}
\hline \multirow[t]{2}{*}{ 表 6} & \multicolumn{4}{|c|}{ アンケート回答者の勤務地（大山寺） } & \multicolumn{2}{|c|}{ （複数回答, 人） } \\
\hline & 集落内 & 大山町内 & 鳥取県内 & 鳥取県外 & その他 & 無回答 \\
\hline 世帯主 & $68 \%(30)$ & $5 \%(2)$ & $0 \%(0)$ & $9 \%(4)$ & $2 \%(1)$ & $16 \%(7)$ \\
\hline 20歳以上住民 & $72 \%(33)$ & $0 \%(0)$ & $28 \%(13)$ & $0 \%(0)$ & $4 \%(2)$ & $7 \%(3$ \\
\hline
\end{tabular}
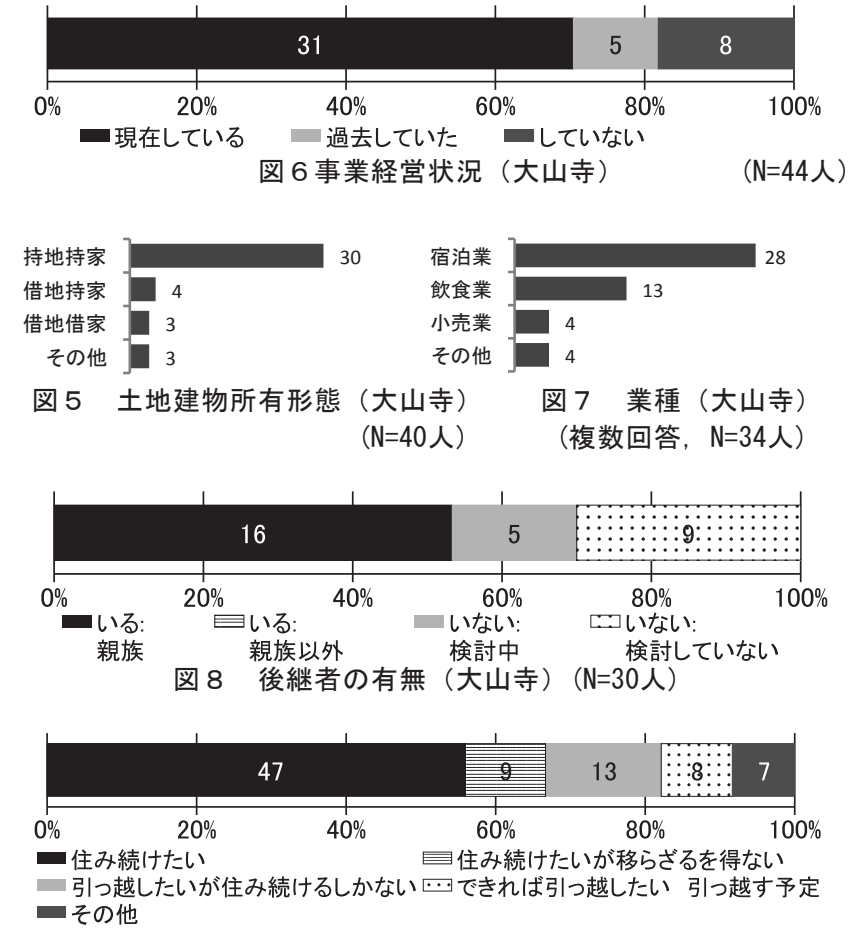

図 9 定住意向（大山寺）( $\mathrm{N}=84$ 人, 世帯主と20歳以上の住民が回答)

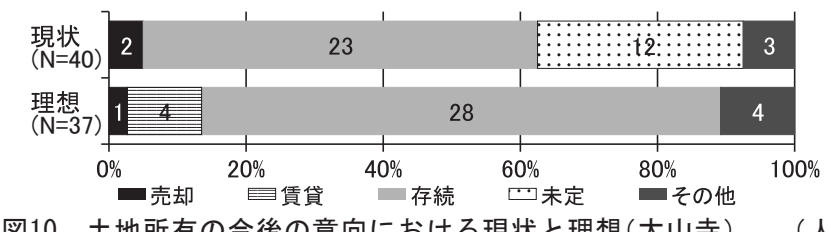

図10 土地所有の今後の意向における現状と理想 (大山寺) (人) 


\section{3-5 公園事業（宿舎）の実態}

土地利用に大きな影響を与える「公園事業」のうち, 集落住民が 事業者となり得る宿舎事業に着目し, その許認可履歴と認可の理由 を分析した。公園事業とは, 公園ごとに作成される「公園計画」に 基づいて定められる利用と保護のための施設, ビジターセンターや キャンプ場, ホテルや旅館などの宿舎などを指す。公園事業は, 国 だけではなく, 地方公共団体, 民間事業者が環境大臣の認可を受け て執行することができる。大山寺集団施設地区の宿舎事業は，2014 年 8 月現在 44 件あり, 集落全体に分布する(図11)。そのうち現在営 業している宿舎事業18件は, 地区内企業のホテル 1 件を除き, す心゙ て集落住民が経営している。また, 一件あたりの増改築の回数は多 く, 宿舎の宿泊機能の充実や規模拡大を目的としたものが多い。そ の認可理由は,「周辺の景観に著しい影響を及ぼすことがなく, 国立 公園の利用促進のために宿舎の許容量を増やすことや設備を整える 必要がある」というものが大半であった。一方で, 利用拠点整備を 一通り終えた 80 年代から廃業による公園事業の廃止が相次ぎ, 現在 では19件が営業していない。公園事業を廃止する場合にも許可申請 が必要であるが，必ずしも守られておらず，公園事業廃止の申請を せず実際には営業していないものも44件中 12 件存在する。近年, 廃 業後利活用されている事業も 7 件あるものの，いずれも宿泊機能は 伴わず，うち 5 件は住民以外の企業が事業者となっている。

このように, 大山寺では, 宿泊機能の充足を目的に, 住民を中心 とした事業者による宿舎事業で積極的に増改築が行なわれてきた。 このような開発は一時的に集落を活性化することに繋がったといえ るものの, 現在では, 廃止の手続きもされず空き家となる公園事業 が増加するなど, 景観保護・地域維持の両面に問題を抱えている。

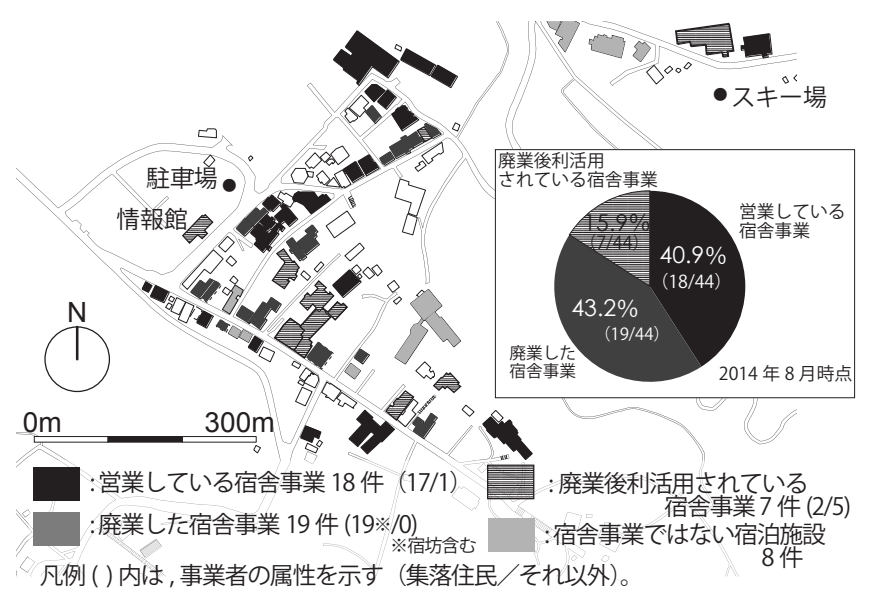

図11＼cjkstart宿舎事業の分布と実態（大山寺）

\section{4. 御岳山集落の土地利用管理 \\ 4-1 集落の形成過程}

集落の変遷を辿ると, 平安時代末には御訔神社の社殿が建立され, 鎌倉時代以降は関東における蔵王権現信仰の中心的な存在であった とされる。江戸時代初頭以降には, 武蔵御嶽神社の神事にあたる御 師（おし）やその親族の暮らす御師集落として発展した。御師の多 くは御岳山を訪れた修験者が定住するに至ったものである ${ }^{16)}$ 。近世 以降には, 御師と檀那との師檀関係が結ばれ, 檀那の神社参詣に際 しては便宜を計るようになり, 神主・社僧・御師の 3 者が神社の運
営組織を作り，これにあたるようになった。享保頃（1716-1740）に は御師家は 36 軒となり, 多少の変化はみられるものの近年まで継続 してきた ${ }^{17)}$ 。また, 明治元年の神仏分離令により，神道的色彩をさ らに濃くしていったが, 御岳山の運営は, 江戸中期より既に社僧が 衰微して, 神主と御師が基軸になっていたため, 何の混乱もなく, 短期間で神仏分離令を受容することができた注11)。このように，御 岳山では，廃仏毁釈の影響をあまり受けなかったため, 現在に至る まで, 山岳信仰集落としての機能が維持されてきたと考えられる。

集落の整備をみると, 1930年代には御岳登山鉄道ケーブルカーの 開通や簡易水道の敷設と, 交通・生活面の整備が進んだ(図 12 上)。 そして，1950年に秩父多摩国立公園に指定され，大山寺と同年1954 年に御岳集団施設地区に指定された。このころから，御師の住宅は 一般客用の宿泊施設を兼衫るようになった。また，1965年頃から宿 泊施設は都青年野外旅行活動宿泊所の指定を受け始め, 都がビジタ 一センターを, 市がふれあいセンターを設置するなど, 拠点整備が 進んだ。一方で，1990年以降は保護・利用の両面に関する大きな動 きはない。そして，2000年には，区域内でこれ以上総合的に整備を 進めていくことが困難であること, 集団施設地区として整備する必 要性を失ったことという理由から, 集団施設地区の指定が解除され, 環境省直轄で面的に整備されるエリアではなくなった。2000年以降 も，特に大きな出来事はないことから，2000年までに整備された集 落空間を現在まで維持しているといえる。

\section{4-2 土地利用変化と土地所有変化 \\ (1) 土地利用変化}

土地台帳によると, 1945年の地目構成は, 御岳山山頂に社寺境内 地, 参道沿いに宅地が広がり, その宅地の間に畑や原野が点在し, その周囲を山林が囲んでいる(図12下)。年代別の地目構成は一様に 山林が最大で, 次いで宅地, 原野が多く, 変化はほとんどない。合 計筆数の変化は, 前期には282筆から304筆, 後期には382筆と, 大山 寺に比べ，それほど多くない(表 7 )。

地目別の筆数変化をみると, 宅地は前期でわずか 2 筆増加したの みである。後期に 23 筆増加しているが，いずれも集団施設地区指定 から25年以上経過してからの分筆であった。山林や原野でも同様の 傾向がみられる。集団施設地区に指定されている間には，道路の拡 充整備が行なわれたが，それ以外の地目の変更はほとんどなかった といえる。また, 集団施設地区から外れた 2000 年以降も変化はない。

\section{(2) 土地所有変化}

年代別に土地所有者の筆数構成比をみると，1945年では個人が $68 \%$ と大半を占め, 次いで社寺が $27 \%$ と多い。一方で公共団体はわ ずか $4 \%$ で，国有地は存在しない(表 7 )。また，個人のうち，神社 門前の広場や飲食店や売店が連なる区域など $13 \%$ は記名共有地であ

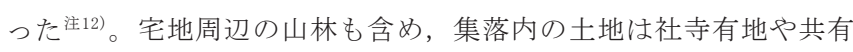
地等, 集落住民による共同所有の形態が多く存在する。前期の構成 比はほとんど変わらず，2010年は公共団体所有が増加した。

土地所有変化の詳細をみると注 13$)$, 前期の变化は 32 筆 $\left(10,945 \mathrm{~m}^{2}\right)$ である (表 8 左)。そのうち, 社寺から個人へ分筆した筆が 19 筆 $(59 \%)$, 面積7, $828 \mathrm{~m}^{2}(72 \%)$ と最も多い。これは, 第二次世界大戦後の農地 改革によって，もともと御師に分与されていた畑を社寺有地から各 戸に払い下げられたものである。次いで, 公共団体から神社への変 化が 7 筆 $(22 \%)$ と多い。これは, 神社参道などもともと神社境内 
地として利用されていた土地である(図12-土地所有1970-A)。また， 個人から公共団体一変化した 3 筆（9）は，私道整備と都立高校 のセミナー八ウスの用地転用に伴う変化 (図12下-同B) である。個 人から個人に分筆した 3 筆は，私道を整備するための分筆であり， 所有者は変化していない。したがって, 利用拠点としての整備の時 期である前期は，一部東京都の所有に変化したものを除き，集落外 から新たに土地所有者が参入することはなく, 集落内の個人や神社 との間での変更があるのみであった。

後期の土地所有の変化は 83 筆 $\left(3,740 \mathrm{~m}^{2}\right)$ である (表 8 右)。筆数 は前期の 2 倍以上変化したが, 面積は 1 ／ 3 程度の変化にとどまる。
そのうち，個人から公共団体へ分筆したものが59筆（71\%)，1,415 $\mathrm{m}^{2}$ と最も多い。これは, 集落の中心を通る道路の拡幅のために, 道 路に隣接する私有地から分筆されたものである（図12-土地所有 2010-C)。また, 個人から公共団体一の変化は, 東京都のビジターセ ンター用地一の転用に伴うものである（図12-同D)。公共団体への変 化に次いで，個人から個人への分筆が11筆と多い。これは私道の整 備を目的としたものが多く, 分筆に伴う土地所有の変化はない。こ のように, 前期と同様に, 後期でも集落外から新たな土地所有者が 参入することはなく, 道路拡幅のための変化やビジターセンター整 備以外では, 特に変化はなかったといえる。これは, 観光地的機能

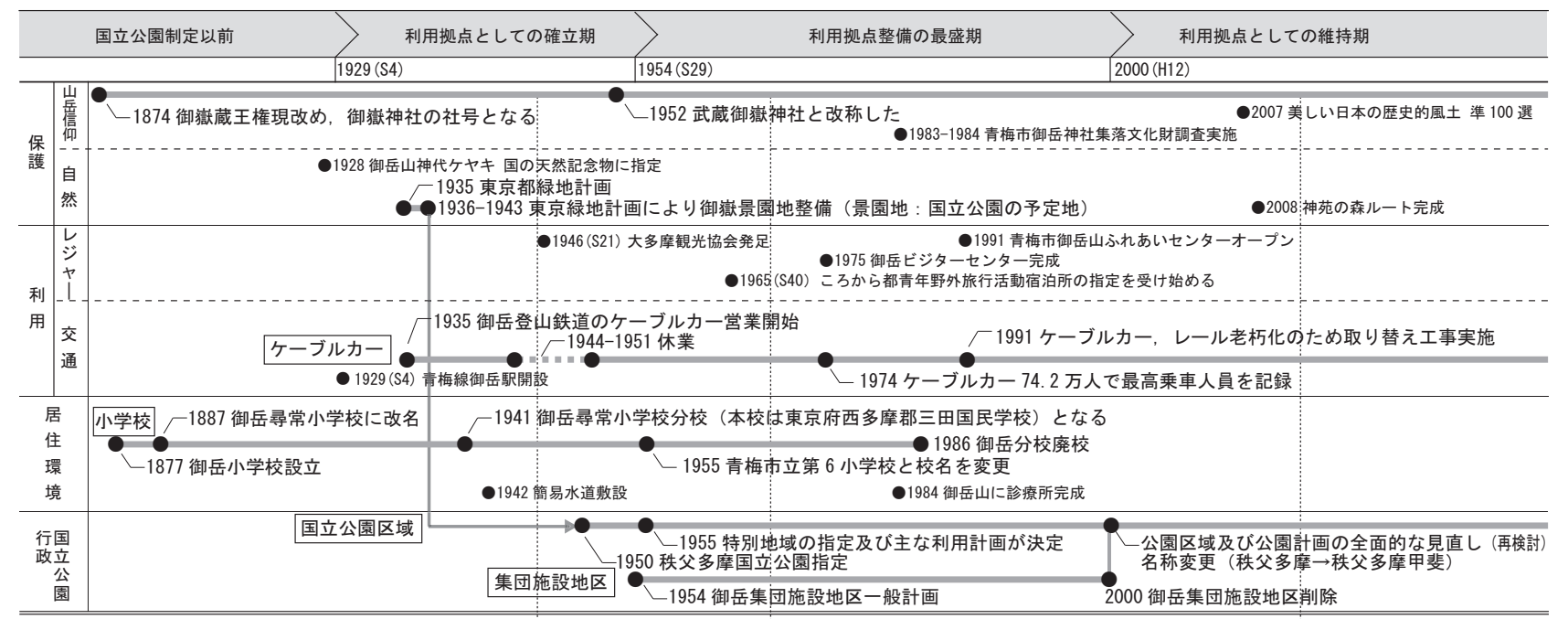

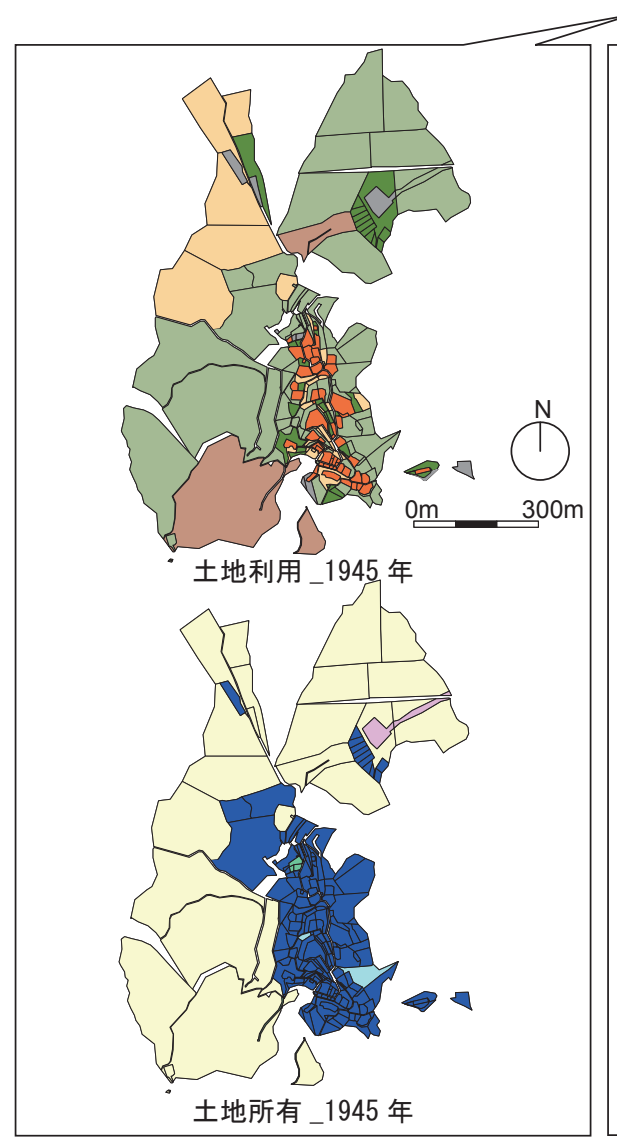

凡例： $\square$ 宅地 $\square$ 原野 $\square$ 畑 $\square$ 不明 土地利用 $\square$ 山林 $\square$ 社寺境内地 $\square$ その他

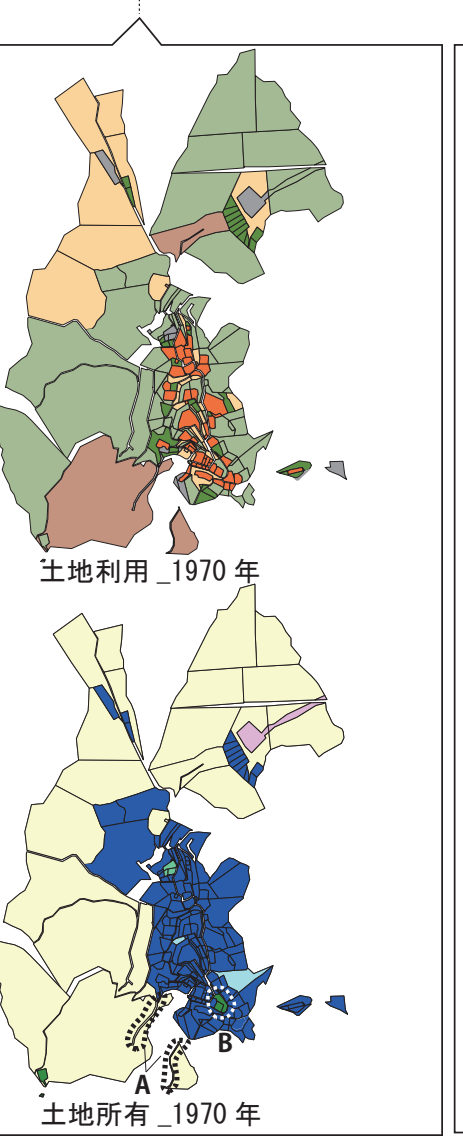

凡例： 土地所有者 $\square$ 個人(地区外) $\square$ 会社(地区外)

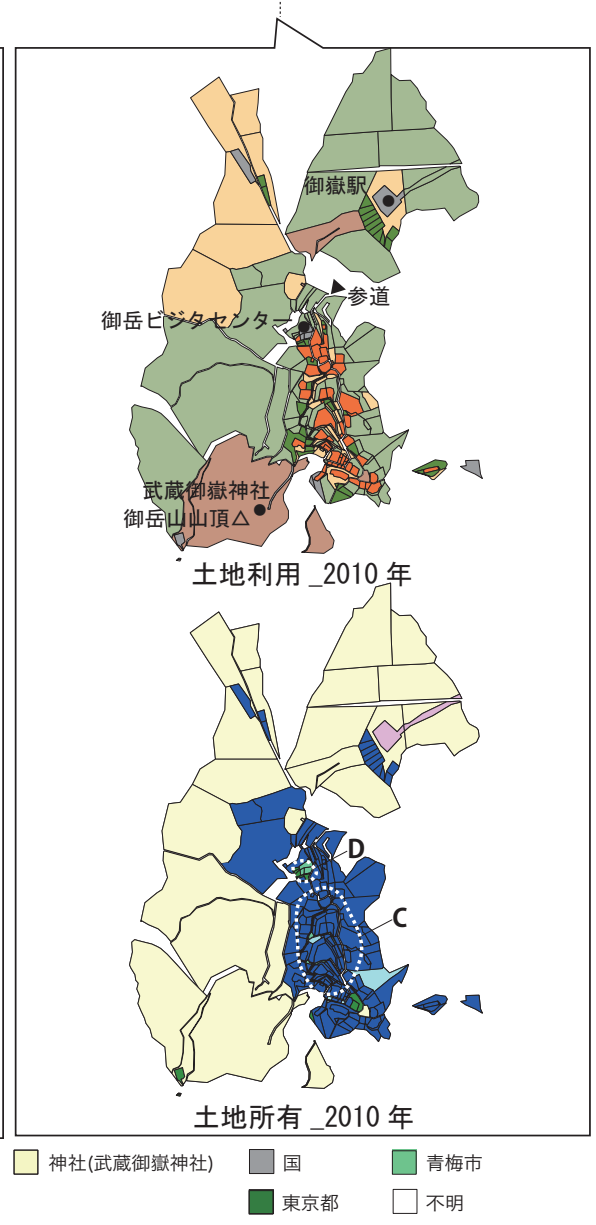

土地所有_2010 年

図12 御岳山の変遷 (上) と土地利用 ·土地所有変遷図 (下) 

や貸与を抑制してきたことが関係している注14)。

\section{4-3 2010年の土地所有別の土地利用実態と土地・建物の管理者}

土地所有の比率が最も大きい私有地は, 集落内の住民と法人が所 る。また, 法人はケーブルカーを運営する鉄道会社に限られ, 個別 に利用・管理されている。

社寺有地は, 山林, 原野, 社寺境内が大半を占める。そのうち山 林は, 東京都に貸すもの, 仲間山に貸すもの注15), 山下, 山上の御 師によって作られた組合である御岳山施行森林組合が管理するもの, の 3 種がみられる。社寺境内の利用と管理の方針は, 御師を含めた 神社関係者による総会の合意のもとで決定されるため注16), 社寺有 地は住民でもある御師によって共同管理されているといえる。その 他に, 山林注17) や, 神社門前の広場, 神社の参道沿いの飲食店や売 店が連なる区域は住民により共同所有されている。共有地の利用・ 管理については, 共有総会で土地所有者の全員の合意が必要なため,

\section{ここでも住民の意思の疎通が図られる集18)。}

公有地は市と都の所有がある。市有地の大半は, 集落内の道路で ある。その他に小学校跡地を御岳ふれあいセンターとして活用寸る 土地を所有しているが，その管理は指定管理者制度により自治会に 委衫られている。事業が開始された2000年以降, 指定管理者制度が

表 7 年代別にみた土地利用と土地所有の関係（御岳山） (筆)

\begin{tabular}{|c|c|c|c|c|c|c|c|c|c|c|}
\hline & & 宅地 & 山林 & 原野 & \begin{tabular}{|c}
$\begin{array}{c}\text { 社寺境 } \\
\text { 内地 }\end{array}$ \\
\end{tabular} & 畑 & その他 & 不明 & \multicolumn{2}{|c|}{ 計 } \\
\hline \multirow{6}{*}{$\begin{array}{l}1 \\
9 \\
4 \\
5 \\
\text { 年 }\end{array}$} & 個人 & 58 & 62 & 25 & & 36 & 9 & 1 & 191 & $68 \%$ \\
\hline & 答社 & & 5 & & & & 1 & & 6 & $2 \%$ \\
\hline & 公共団梁 & & 1 & 2 & 2 & & 5 & & 10 & $4 \%$ \\
\hline & 神社 & & 45 & 16 & 10 & 4 & & & 75 & $27 \%$ \\
\hline & \multirow{2}{*}{ 計 } & 58 & 113 & 43 & 12 & 40 & 15 & 1 & \multicolumn{2}{|c|}{282} \\
\hline & & $21 \%$ & $40 \%$ & $15 \%$ & $4 \%$ & $14 \%$ & $5 \%$ & $0 \%$ & \multicolumn{2}{|c|}{ "100\% } \\
\hline \multirow{6}{*}{$\begin{array}{c}1 \\
9 \\
7 \\
0 \\
\text { 年 }\end{array}$} & 個人 & 59 & 62 & 27 & & $\overline{52}$ & 10 & & 2103 & $69 \%$ \\
\hline & 答社 & & 5 & & & & 1 & & 6 & $2 \%$ \\
\hline & 公共団体 & 1 & 1 & & & & 4 & & 6 & $2 \%$ \\
\hline & 神社 & & 45 & 19 & 14 & & 4 & & 82 & $27 \%$ \\
\hline & \multirow{2}{*}{ 計 } & 60 & 113 & 46 & 14 & 52 & 19 & 0 & \multicolumn{2}{|c|}{304} \\
\hline & & $20 \%$ & $37 \%$ & $15 \%$ & $5 \%$ & $17 \%$ & $6 \%$ & $0 \%$ & \multicolumn{2}{|c|}{ "100\% } \\
\hline \multirow{6}{*}{$\begin{array}{c}2 \\
0 \\
1 \\
0 \\
\text { 年 }\end{array}$} & 個人 & $\overline{64}$ & 65 & 31 & $\overline{11}$ & 49 & 7 & & 2173 & $57 \%$ \\
\hline & 答社 & & 5 & & & & 1 & & 6 & $2 \%$ \\
\hline & 公共団体 & 18 & 18 & 15 & & 9 & 12 & & 72 & $19 \%$ \\
\hline & 神社 & 1 & 47 & 20 & 16 & & 3 & & 87 & $23 \%$ \\
\hline & \multirow{2}{*}{ |計 } & 83 & 135 & 66 & 17 & 58 & 23 & & \multicolumn{2}{|c|}{382} \\
\hline & & $22 \%$ & $35 \%$ & $17 \%$ & $4 \%$ & $15 \%$ & $6 \%$ & $0 \%$ & \multicolumn{2}{|c|}{$100 \%$} \\
\hline
\end{tabular}

を拡大寸る中で, 社寺関係者による社寺関係者以外への土地の売却 有する。宅地の 8 割と宅地の間の山林は集落内の住民が所有してい

表 9 アンケート回答者の年代（御岳山） (人)

\begin{tabular}{|l|c|c|c|c|c|c|c|c|c|}
\hline & 20 代 & 30 代 & 40 代 & 50 代 & 60 代 & 70 代 & 80 代 & 無回答 & 計 \\
\hline 世帯主 & $0 \%(0)$ & $0 \%(0)$ & $3 \%(1)$ & $42 \%(13)$ & $19 \%(6)$ & $19 \%(6)$ & $7 \%(2)$ & $10 \%(3)$ & 31 \\
\hline 20 歳以上住民 & $8 \%(3)$ & $22 \%(8)$ & $19 \%(7)$ & $16 \%(6)$ & $16 \%(6)$ & $14 \%(5)$ & $3 \%(1)$ & $3 \%(1)$ & 37 \\
\hline
\end{tabular}

表10 アンケート回答者の勤務地（御岳山）（複数回答, 人）

\begin{tabular}{|l|r|r|r|r|r|r|}
\hline & 集落内 & 青梅市内 & 東京都内 & 東京都外 & その他 & 無回答 \\
\hline 世带主 & $68 \%(21)$ & $13 \%(4)$ & $3 \%(1)$ & $3 \%(1)$ & $7 \%(2)$ & $16 \%(5)$ \\
\hline 20 歳以上住民 & $87 \%(32)$ & $8 \%(3)$ & $0 \%(0)$ & $0 \%(0)$ & $0 \%(0)$ & $5 \%(2)$ \\
\hline
\end{tabular}

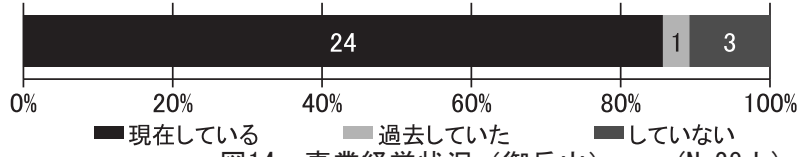

図14 事業経営状況（御岳山）（N=28人)

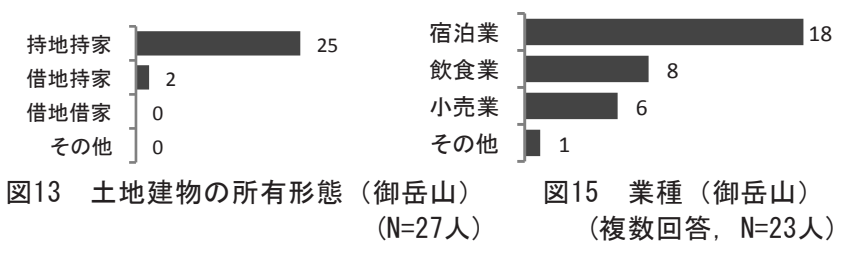

適用されるまでの間も，管理は自治会へ委託されている注19)。都有 地は, ビジターセンターの敷地に限られ，管理は東京都である。こ のように, 私有地以外の土地は宅地のみならず山林や原野も含めた 大部分が共有地, 社寺有地である。そのため, 住民は, 管理委託業 者（自治会員）や御師，個人経営者といった複数の立場として管理 に携わっている。このような土地所有構造は, 各土地の利用の方向 性を決定する際に，住民相互で意思疎通を図ることを容易にする。 寸なわち, 集団施設地区として利用拠点のために開発が行なわれや すい状況にあったにもかかわらず，国立公園指定以前から続く御師 集落としての住民主体の重層的な管理方法が, 集落の極端な観光地 化を抑制し，集落全体の一体的な土地利用に繋がっている。

\section{4-4 集落内の住民の意向}

アンケートの回答を得た世帯主の年代は, 50 代から70代が中心で あった (表 9 )。勤務地は世帯主 $68 \%$ ，20歳以上の住民 $87 \%$ と共に集 落内が最も多く, 職住一体の暮らしをしている(表10)。土地・建物 の所有形態は持地持家が93\% と多く(図13)，86\%の世帯が現在事業 を経営している(図14)。業種は, 宿泊業が18人で最も多く, 次いで

表8 1945-1970-2010年の土地所有変化(御岳山)

\begin{tabular}{|c|c|c|c|c|c|c|c|c|c|c|c|c|c|c|c|c|}
\hline \multirow{2}{*}{\multicolumn{2}{|c|}{\begin{tabular}{|l|} 
上段:筆数(筆) \\
下段:面積( $\left.\mathrm{m}^{2}\right)$
\end{tabular}}} & \multicolumn{8}{|c|}{ 1970年 土地所有 } & \multirow{2}{*}{\multicolumn{2}{|c|}{$\begin{array}{l}\text { 上段:筆数(筆) } \\
\text { 下段:面積 }\left(\mathrm{m}^{2}\right)\end{array}$}} & \multicolumn{5}{|c|}{ 2010年 土地所有 } \\
\hline & & 個人 & $\begin{array}{l}\text { 分筆前 } \\
\text { 個人) }\end{array}$ & 法人 & 社寺 & \begin{tabular}{|l|} 
分筆前 \\
(社寺)
\end{tabular} & $\begin{array}{l}\text { 公共 } \\
\text { 団体 }\end{array}$ & $\begin{array}{l}\text { 分筆前 } \\
\text { (公共团体) }\end{array}$ & 総計 & & & 個人 & 法人 & 社寺 & $\begin{array}{l}\text { 公共 } \\
\text { 団体 }\end{array}$ & 総計 \\
\hline \multirow{13}{*}{$\mid \begin{array}{l}1 \\
9 \\
4 \\
5 \\
\text { 年 }\end{array}$} & 個人 & $\begin{array}{r}188 \\
185586\end{array}$ & & & & & 3 & & 191 & \multirow{5}{*}{9} & \multirow{2}{*}{ 個人 } & 205 & & 1 & 4 & 210 \\
\hline & & 125,586 & & & & & & & 126,488 & & & 132,515 & & 505 & 683 & 133,703 \\
\hline & 分筆前 & 3 & 73 & & & & & & 76 & & 分筆前 & 11 & & 3 & 59 & 73 \\
\hline & (個人) & 288 & 1,788 & & & & & & 2,077 & & (個人) & 362 & & 11 & 1,415 & 1,788 \\
\hline & 法人 & & & $\begin{array}{c}6 \\
5,773\end{array}$ & & & & & $\begin{array}{r}6 \\
5,773\end{array}$ & & 法人 & & $\begin{array}{r}6 \\
5,773\end{array}$ & & & $\begin{array}{r}6 \\
5,773\end{array}$ \\
\hline & 社寺 & & & & \begin{tabular}{|r|}
75 \\
$1,052,301$
\end{tabular} & & & & $\begin{array}{r}75 \\
1,052,301\end{array}$ & \multicolumn{2}{|l|}{ 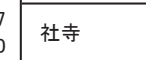 } & & & \begin{tabular}{|r|}
82 \\
$1,054,228$ \\
\end{tabular} & & $\begin{array}{r}82 \\
1,054,228\end{array}$ \\
\hline & 分筆前 & 19 & & & & 5 & & & 24 & \multirow[t]{2}{*}{ 年 } & 分筆前 & 1 & & 1 & 3 & 5 \\
\hline & (社寺) & 7,828 & & & & 764 & & & 8,592 & & (社寺) & 28 & & 23 & 713 & 764 \\
\hline & 公共団体 & & & & $\begin{array}{r}7 \\
1,927\end{array}$ & & $\begin{array}{r}3 \\
994 \\
\end{array}$ & & $\begin{array}{r}10 \\
2,921\end{array}$ & \multirow{2}{*}{\begin{tabular}{|l}
$\mid \pm$ \\
地 \\
所 \\
有
\end{tabular}} & 公共団体 & & & & \begin{tabular}{r|}
6 \\
1,895
\end{tabular} & $\begin{array}{r}6 \\
1,895\end{array}$ \\
\hline & $\begin{array}{r}\text { 分筆前 } \\
\text { (公共団体) }\end{array}$ & & & & & & & & $\begin{array}{l}0 \\
0\end{array}$ & & $\begin{array}{r}\text { 分筆前 } \\
\text { (公共団体) }\end{array}$ & & & & & $\begin{array}{l}0 \\
0 \\
0\end{array}$ \\
\hline & 1945-1970年 & 22 & 0 & 0 & 7 & 0 & 3 & $\overline{0}$ & 32 & & \multirow{2}{*}{ 1945-1970年 } & 12 & 0 & 5 & 66 & 83 \\
\hline & で変化した筆 & 8,116 & 0 & 0 & 1,927 & 0 & 901 & 0 & 10,945 & & & 390 & 0 & 539 & 2,811 & 3,740 \\
\hline & 総計 & $\begin{array}{r}210 \\
133,703 \\
\end{array}$ & \begin{tabular}{r|}
73 \\
1,788 \\
\end{tabular} & \begin{tabular}{r|}
6 \\
5,773 \\
\end{tabular} & \begin{tabular}{|r|}
82 \\
$1,054,228$ \\
\end{tabular} & \begin{tabular}{r|}
5 \\
764 \\
\end{tabular} & $\begin{array}{r}6 \\
1,895 \\
\end{array}$ & $\begin{array}{l}0 \\
0\end{array}$ & $\begin{array}{r}382 \\
1,198,152 \\
\end{array}$ & \multicolumn{2}{|r|}{ 総計 } & \begin{tabular}{|r|}
217 \\
132,905 \\
\end{tabular} & \begin{tabular}{r|}
6 \\
5,773 \\
\end{tabular} & \begin{tabular}{|r|}
87 \\
$1,054,767$ \\
\end{tabular} & $\begin{array}{r}72 \\
4,706 \\
\end{array}$ & $\begin{array}{r}382 \\
1,198,152\end{array}$ \\
\hline
\end{tabular}

飲食業, 小売業であり， 宿泊業と兼業する場合 が多い(図15)。また, 現在事業を経営してい る世帯の $91 \%$ は親族が 後継者に決まっている ことから, 今後も事業 は後継者により継続さ れると推測できる(図 16）。定住意向をみると, 86\%は住夕続けたいと している(図17)。アン ケート自由回答より， その理由には神職や文 

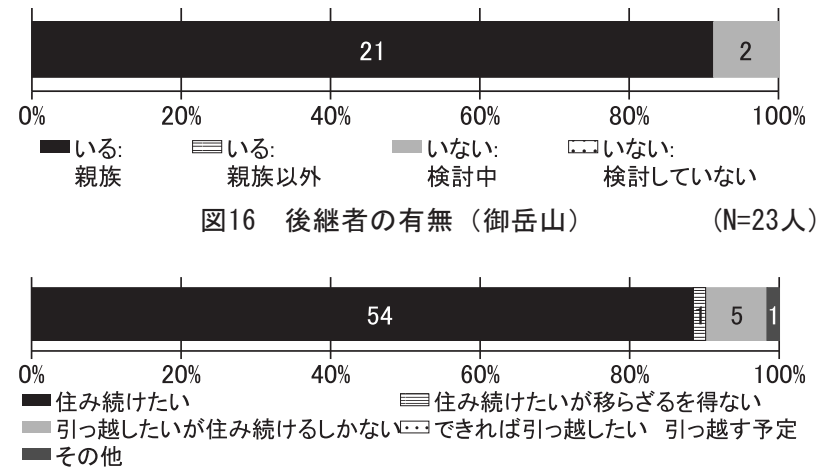

図17 定住意向（御岳山）( $\mathrm{N}=61$ 人，世帯主と20歳以上の住民が回答）

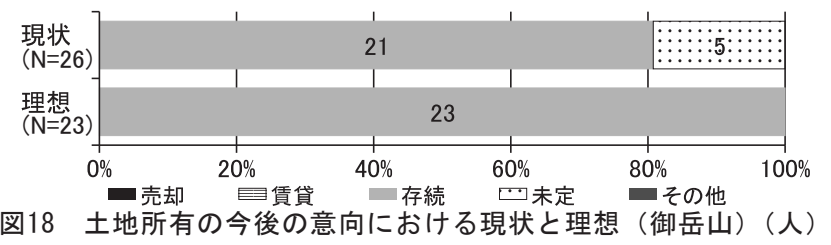

化の継承, 人間関係の良さが挙げられた。土地所有の今後の意向を みると, 理想の $100 \%$ に対して, 現状ではそのまま存続する予定が $81 \%$ で, 現状と理想がともに高い割合を示す(図18)。自由回答では, 存続意向の理由として, 伝統・文化を継承するためや神職の使命で あるが挙げられた。住民の意識としても, 御師としての役割を果た すことが重要視されていることが窥える。

\section{4-5 公園事業 (宿舎) の実態}

公園事業台帳によると, 御岳山の公園事業（宿舎事業）は, 2014 年 5 月現在17件である。17件す心゙ての公園事業者は地域住民で, 御 師住民兼旅館の経営者である。増改築を行うために公園事業の認可 を受けたものがほとんどである。このような動きは, 利用拠点整備 としての最盛期に集中している。さらに1965年頃から東京都青少年 野外旅行宿泊所の指定を受けたことも重なり, 宿泊者の増加に伴い 御師住居の拡充が必要となったことが影響している。集団施設地区 から外れた 2000 年以降の許認可数はわずか 2 件で, ほとんど動きが ない。また, 大山寺でみられたような廃業している公園事業もなく, 現在まで公園事業として適切に機能しているといえる。

\section{5. まとめ}

大山寺と御岳山の両集落について各分析結果を比較した上で, 集 落内の土地利用管理の特徵と課題をまとめる。

\section{（1）両集落の変遷及び土地利用変化}

大山寺では, 1868 (明治元) 年に廃仏毀釈を命ぜられ, 集落は急速 に衰退した。現在は, 僧坊の大半は現存しておらず旅館街に姿を変え ている。国立公園指定後, 1954年に集団施設地区に指定され，道路 や利用拠点としての施設整備, スキー場開発が同時期に行なわれた。 2004年以降は, 歴史的町並みの保護, 地域活性化など各分野で, 官・ 民さまざまな主体による活動が始動している。土地利用（地目）か らみると, 社寺有地を中心に宅地化が進しだ。山岳信仰集落として の機能が衰退した大山寺では, 集落再生のために積極的な観光地化 が進んだといえる。

一方, 御岳山では, 廃仏毀釈の影響をあまり受けず, 現在まで山 岳信仰集落としての機能が維持されている。1954年に集団施設地区
に指定された後，ビジターセンター等が設けられ，宿坊は一般客用 の宿泊施設を兼衩るようになった。また，道路拡幅などのインフラ 整備が行なわれたが，その他の土地利用変化はほとんどなかった。 両集落では，国立公園指定や集団施設地区指定をきっかけに異な る土地利用の変化がみられた。両集落の土地利用変化に差が生じた 背景には, 山岳信仰集落としての機能維持の度合いが関係している。

\section{（2）両集落の土地所有変化及び土地所有者の意向}

大山寺では，特に1954年集団施設地区指定後に，法人の新規参入 や集落外の土地所有者が増加するなど変化が著しかった。大山寺の 土地所有構造は, 社寺, 公共団体, 個人と様々な所有の変化を伴い, 流動的であった。このような土地所有変化が見られたエリアは土地 利用変化の著しいエリアと重なっているため, 集落の土地利用の変 容は，土地所有者の所有状況の変化と連動している。居住者のうち 約 7 割は定住意向を示しているにもかかわらず，現在事業をしてい る世帯のうち約 5 割は後継者がおらず, 検討していない世帯も多い。 このような状況は，今後の土地・建物の低未利用化にも繋がること が懸念される。

一方, 御岳山では, 土地所有者の大半は集落住民であり, 土地所 有の変化は必要最低限のインフラ整備のために公有地化した程度で あった。また，私有地以外に社寺有地や共有地のような集落住民に よる共同所有の形態が存在する。国立公園の利用施設が建つ公有地 も自治会に委託・管理されている。また, 現在事業を行なう世帯の うち約 9 割が親族に後継者がいることからも, 今後も集落住民によ り所有・管理されると予測できる。すなわち，国立公園指定以前の 土地所有形態が守られた御岳山と, 法人を中心とした新しい所有者 が参入した大山寺では, 土地利用の変化に差が生じたと考えられる。

\section{（3）両集落の土地・建物の管理実態と管理上の課題}

大山寺では，公有地は管理委託制度を利用寸ることで，委託業者 による一体的な管理がされている。このような管理方法は，集落の 人口減が著しい中で, 集落の規模に依存しない維持管理を行なう上 で有効は方法となりうる。しかしながら，私有地では集落内外の土 地所有者が存在するため, 住民により持続的に管理されている場所 と, 後継者問題などを背景に低・未利用地化が進んでいる場所が混 在している。集落外の個人が所有寸る土地では，管理が行き届かな い状況にあるため, 集落内外の土地所有者との連携が不可欠である。

一方，御岳山では，宅地は住民が，山林や原野は住民で構成され る自治会と御師などの神社関係者が，公有地は公共団体から管理を 委託された自治会が，共同・調整しながらそれぞれ管理している。 土地利用や管理の方針を決定する際には, 社寺有地では神社関係者 の, 共有地では住民を中心とする土地所有者の全員の合意が必要な ため, 住民相互の意思疎通が図られている。御岳山では, 大山寺と 同様に，集団施設地区として開発が行なわれや寸い状況にあったに もかかわらず，国立公園指定以前から続く御師集落としての住民主 体の重層的な管理方法が，集落の極端な観光地化を抑制し，集落全 体の一体的な土地利用に繋がっている。

\section{（4）公園事業の履歴と現在の課題}

両集落では, 既存の建物を増改築する際に, 公園事業の認可を申 請する場合が大半であった。また, 環境省は, 周辺の景観に著しい 影響を及ぼすことがなければ，国立公園の利用促進のために，公園 事業を認可していた。そのため, 大山寺では観光ニーズの高まりに 
応じて繰り返し増改築が行なわれた。しかし社会状況が変化した現 在では, 廃業による公園事業の廃止が相次ぐなどの問題を抱えてい る。一方, 御岳山は, 大山寺に比べて, 増改築等の開発行為が行な われた数は少なく, 近年はほとんどみられない。このように, 大山 寺と御岳山では，同じ規制がかけられているにもかかわらず，公園 事業の許認可状況が異なる。これは，公園利用の促進を目的とした 集団施設地区制度や公園事業によって, 厳しい規制がほとんどなく 開発行為が進めや寸い状況にある中で, 開発の程度の調整が個々の 公園事業者の意志に任されていることが影響していると考えらえる。 寸なわち, 土地所有が多様化した大山寺では, 全体の土地利用のコ ントロールがないため，個々の開発がそれぞれに進んだ。

以上のように, 両集落とも国立公園制度や集団施設地区指定によ り開発が行なわれや寸い状沉にある中で, 土地利用の変化の度合い に差が生じた背景には, 山岳信仰集落としての機能がどの程度維持 されているか, 土地所有構造の変化を伴ったか, そして集落内で土 地利用や所有に対するコントロール機能が存在していたかが関係し ていた。大山寺では現在, 集落の維持が困難な状況にあるため, こ れまで大山寺で行なわれてきた官民さまざまな主体による景観整備 や利用者増加を目指した活性化計画に加えて, 今後は, 御岳山のよ うな住民主体の管理体制の構築や, 構築に向けた支援も必要である。 本研究では 2 事例のみの分析であったが, 集落数の追加や協働管 理体制の検討は，今度の課題としたい。

\section{謝辞}

資料提供とアンケート及びヒアリング調査にご協力頂いた，両集 落の住民のみなさま, 米子自然環境事務所のみなさま, 奥多摩自然 保護官事務所のみなさまなど関係者の方々に心から謝意を表します。

\section{参考文献}

1）加藤峰夫 : 自然公園シリーズ3 国立公園の法と制度, 古今書院, p. 286, 2008

2）財団法人国立公園協会: 平成 23 年度関係者の協働による国立公園の魅力 向上の方策検討調査業務報告書, 2011

3）環境省：国立公園における協働型管理運営を進めるための提言，2013, 3, http://www. env. go.jp/press/files/jp/24150.pdf, 2015.05.05取得

4）小椋弘佳・樋口秀・細田智久 ・熊谷昌彦：国立公園の利用促進等に向け た集団施設地区の課題と取り組み実態に関する研究-集団施設地区内の 集落規模に着目して-, 日本建築学会計画系論文集 第 80 巻 第 716 号, pp. 2261-2271，2015

5）加藤峰夫：国立公園管理における公園内のコミュニティ（地域社会）の 役割，エコノミア第43巻第2号（通巻第114号)，pp. 48-69, 1992

6）加藤峰夫：「地域」が支える「国立公園」，国立公園No. 639，pp. 6-9，2005

7）川﨑興太 : 国立公園制度の運用実態と課題 - 裏磐梯に関する研究 (その 2)，日本都市計画学会都市計画報告集No. 11, pp. 126-133, 2013

8）小椋弘佳・細田智久 ・熊谷昌彦：大山隠岐国立公園大山寺地区における 土地所有形態と住民意識からみた課題に関する研究, 日本建築学会技術 報告集 18，38, pp. 313-318，2012

9）長野 覺 : 英彦山修験道の歴史地理学的研究, 名著出版, 1987

10) 藤本利治：門前町, 古今書院, pp. $72-74,1970$

11）和歌森太郎：山伏, 付録 信仰対象の日本の山々, 中公新書, pp. 177-195, 1964

12）環境庁：秩父多摩甲斐国立公園指定書及び公園計画書，2000, 8

13）大山町誌編さん委員会／編：大山町誌，大山町， 1980

14）青梅市史編さん委員会 : 青梅市史 (上巻, 下巻), 1995

15）鳥取県西伯郡大山町教育委員会：大山僧坊跡調查報告書，序文，2011

16）西海賢二等：日本の霊山読み解き事典，柏書房，pp. 160-161, 2014

17）東京都教育委員会: 青梅市御岳神社御師集落文化財調查報告, p. 17, 1986
注

注1）自然公園地域（国立・国定公園，都道府県立自然公園）は，許可制の㛜 しい土地利用規制が適用される「特別地域 (自然公園法20条)」と, 届出制 の緩い規制が適用される「普通地域 (同法33条)」とに大分される。特別地 域には，第一種から第三種と特別保護地区の区別がある。

注2）集団施設地区（自然公園法第36条第1項）の区域は原則として第二種特 別地域に定められ, 地形, 植生等の自然条件を勘案しつつ, 利用及び管理 のための施設の種類と規模に応じて定めるものである。国立公園利用者の 多くが利用する拠点を面的に整備できる地区と位置づけられる。

注3）各集団施設地区を担当する自然保護官事務所と自然環境事務所の自然保 護官へのアンケートを実施し，国立公園区域内または区域周辺の山岳信仰 集落の有無と集落名を聞いた。調査期間は，2012.9.1-2012.10.4, 配布数 119 ，有効回収数 94 , 回収率 $79.0 \%$ 。

注4）指定解除後, 集団施設地区内の園地や宿舎, 休㮩所, 博物展示施設, 道 路は，公園事業の単独施設に振り替えられている。

注5）土地利用と土地所有の履歴を確認できる資料は，法務局所管の登記簿， 自治体所管の土地台帳が挙げられる。本研究では対象集落を含む大字単位 での履歴を明らかにすることを目的としているため, 筆の総数は 800 筆を超 える。そこで，登記簿と同一の情報が得られ，かつ費用がほとんどかから ず, 集落全体の情報を一括して得ることの出来る土地台帳を用いた。また, 土地台帳は手書き資料のため, 地目 ・所有者・面積の情報に関して一部不 明な情報が含まれるものの, 集落全体の傾向を捉える際には大きな影響を 及ばさないと判断した。なお，土地台帳は，自治体によって情報公開の度 合いは異なるが, 基本的には一般公開されている。変遷図の作成にあたり, 大山寺では鳥取地方法務局米子支局所管の地籍図，鳥取県西伯郡大山町所 管の土地台帳を, 御岳山では東京都青梅市所管の公図と土地台帳を用いた。 なお, 両集落の区域が広域であるため, 土地利用・土地所有変遷図は, 全 体から以下に示寸集落部分を切り取った形で掲載した。

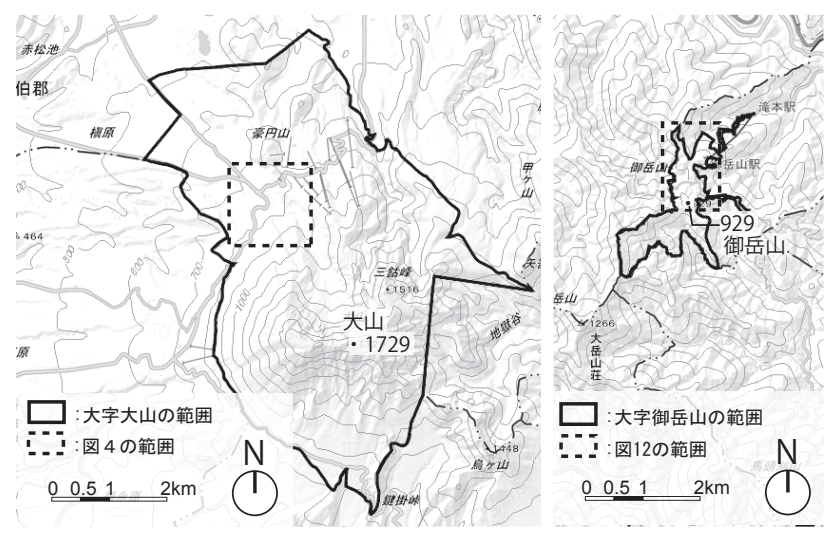

注6）大山寺の公園事業（宿舎）は，米子自然環境事務所所管の公園事業台帳 (2014.8.12閲覽) を,御岳山については奥多摩自然保護官事務所所管の公 園事業台帳（2014.5.15閲覧）を閲覧した。

注7）現地調査とゼンリン住宅地図西伯郡大山町（2011.8）により確認した。 注8）表中の面積の值は, 土地台帳で確認できなかったものについては除外し

ている。また，筆数は2010年時点のものを基準とし，1970年と1945年時点

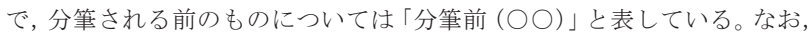
合筆はみられなかった。そして, 表中の太枠は, 所有者の属性が変化して いないものを表している。

注9）2015.9.18大山寺住職へのヒアリングによる。

注10）2014.8.12の米子自然環境事務所自然保護官へのヒアリングによる。

注11）参考文献17), p. 18

注12）土地台帳には「○○(個人名), 他 $○$ 名」と記載されており, 記名共有 の形が取られている。そのため, 表 7 では, 個人の筆として数えた。 注13）現地調査とゼンリン住宅地図青梅市（2010.2）により確認した。 注14）参考文献17), p. 12

注15）仲間山（なかまやま）とは $4 \sim 15$ 人の仲間が山林を借り受け，植林経 営をするものである。

注16）2015.7.27武蔵御嶽神社神主へのヒアリングによる。

注17）共有林は，持分を持つ者が利用する。持分は30口，山上の社家が持つ。 注18）2014.6.8御師団代表者へのヒアリングによる。

注19）2015.3.3青梅市へのヒアリングによる。 


\title{
STUDY ON LAND USE MANAGEMENT OF DAISEN-JI VILLAGE AND MITAKESAN-SANJO VILLAGE IN NATIONAL PARKS
}

\section{Hiroka OGURA* and Shu HIGUCHI**}

\author{
* Assist. Prof., Nagaoka University of Technology, M.Eng.
}

** Assoc. Prof., Nagaoka University of Technology, Dr.Eng.

This study aims to clarify the situation of the land use management and the landownership change in the village located in special zone of National Park through the case study of Daisen-ji village and Mitakesan-Sanjyo village.

We clarify the following as the results.

(1) Land use change in both villages

The land use of both villages has changed by the process of maintaining it as a service center in national park. On the other hand, there were a lot of land classification changes from the land of temple and shrine precincts to the housing lot in Daisen-ji village at the time of setting the facility complexes. At Daisen-ji village, accommodations, the loan skiing shop, and the souvenir shop were constructed at the same time as the infrastructure improvement and various land uses exist together now. In Mitakesan village, there has been little change in the land classification and the improvement of road occurred mainly.

(2) Land ownership change and intentions of landowner in both villages

On the other hand, at Daisen-ji village, the new entry of the companies and the landowners outside the village had increased especially after setting the facility complexes. And, the owners in the inside and outside of the village are existing together now. Moreover, there is no successor in about 47 percent of households that manage lodgings. It is feared that such a situation causes the future low or unused lands and buildings.

As for the land ownership of Mitakesan villlage, the majority of areas are privately owned land in the village, company-owned land, and the corporate estate by residents. Because it has been controlled excluding the land sale and the loan between the people related to the temple and shrine, the change in the land ownership was limited to extent in which the privately owned area was changed to the publicly-owned land for necessary minimum infrastructure improvement. Moreover, the almost 90 percent of the households have the successor and we can expect that the ownership and management by the resident in the village will continue in the future.

So, it is thought that the difference arise in the change of the land use between Daise-ji village that new owners mainly consisted of company entered and Mitakesan village where land ownership before designation of national park was defended.

(3) The situation and issue on the management of lands and buildings at both villages

For Daisen-ji village, a lot of landowners in and outside the village manage individually. Especially, the privately owned area has a lot of problems such as increase of the unused land with incomplete management. And because the facility complexes system doesn't have a function to control the land use in the entire district, the development by each landowner has advanced individually. For Mitakesan village, the resident and the community composed of the resident owns not only the building lot but also the forest and uncultivated field and manages there with cooperation and adjustment. As a result, the land use doesn't change rapidly, and the land use management of the entire village space is enabled. 